Summer 7-21-2021

\title{
Face-to-Face Nursing Promotion of Cardiac Rehabilitation
}

Marika Whitaker

University of St. Augustine for Health Sciences, m.whitaker@usa.edu

DOI: https://doi.org/10.46409/sr.JAIJ7944

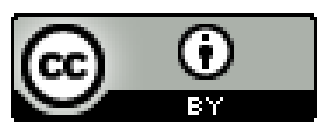

This work is licensed under a Creative Commons Attribution 4.0 License.

Follow this and additional works at: https://soar.usa.edu/scholprojects

Part of the Cardiology Commons, Cardiovascular Diseases Commons, and the Nursing Commons

\section{Recommended Citation}

Whitaker, M. (2021). Face-to-Face Nursing Promotion of Cardiac Rehabilitation. [Doctoral project, University of St Augustine for Health Sciences]. SOAR @ USA: Student Scholarly Projects Collection. https://doi.org/10.46409/sr.JAIJ7944

This Scholarly Project is brought to you for free and open access by the Student Research at SOAR @ USA. It has been accepted for inclusion in Student Scholarly Projects by an authorized administrator of SOAR @ USA. For more information, please contact soar@usa.edu, erobinson@usa.edu. 
Summer 7-21-2021

\section{Face-to-Face Nursing Promotion of Cardiac Rehabilitation}

Marika Whitaker

Follow this and additional works at: https://soar.usa.edu/scholprojects

Part of the Cardiovascular Diseases Commons, and the Nursing Commons 
Face-to-Face Nursing Promotion of Cardiac Rehabilitation

Marika Whitaker MSN, MHA, RN

School of Nursing, University of St. Augustine for Health Sciences

This Manuscript Partially Fulfills the Requirements for the Doctor of Nursing Practice Program and is Approved by:

Camille Payne, Ph.D., RN

Cathy Stankiewicz, DNP, RN, CPHQ

Approved: July 27, 2021 


\begin{abstract}
Practice Problem: The burden of cardiovascular disease is rising at global and national levels, and cardiac rehabilitation is recognized as one of the most beneficial and cost-effective strategies to manage it. One significant problem globally, nationally, and locally is the low numbers of eligible patients who enroll in cardiac rehabilitation.

PICOT: In patients with isolated coronary artery bypass graft (CABG) (P), how does face-toface nursing promotion of cardiac rehabilitation (I) compared to the patients who do not have face-to-face nursing promotion (C), affect the percentage of patients enrolling in cardiac rehabilitation after discharge $(\mathrm{O})$ within 8 weeks $(\mathrm{T})$ ?

Evidence: The evidence used to guide this project included the need for a healthcare organization to have a systematic process for cardiac rehabilitation enrollment, face-to-face nursing promotion, improvement of the healthcare team's knowledge about cardiac rehabilitation, and identification of patient barriers that hinder cardiac rehabilitation enrollment. Intervention: A systematic approach for cardiac rehabilitation was developed using the interprofessional team. After the healthcare team received standardized education, nurses in various roles provided face-to-face promotion, the ARNPs endorsed cardiac rehabilitation, and the care managers addressed barriers.
\end{abstract}

Outcome: The cardiac rehabilitation enrollment rate increased by $16 \%$ among all patients admitted with an isolated CABG on the pilot unit.

Conclusion: Implementation of face-to-face nursing promotion, ARNP endorsement, and reducing barriers were clinically significant in increasing the cardiac rehabilitation enrollment rate. 


\section{Face-to-Face Nursing Promotion of Cardiac Rehabilitation}

Cardiovascular disease (CVD), also known as heart disease, is a global and national epidemic. Heart disease remains the leading cause of death globally and in the United States (American Heart Association, 2019). In 2016, global deaths from heart disease reached 17.6 million, and it is estimated by 2030, the death rate will reach 23.6 million (American Heart Association, 2019). In the United States, as of November 2017, it was estimated 121.5 million adults, approximately 48\%, have some form of cardiovascular disease (Benjamin et al., 2019).

The burden of cardiovascular disease is rising at global and national levels, and cardiac rehabilitation $(\mathrm{CR})$ is recognized as one of the most beneficial and cost-effective strategies to manage it (Supervia et al., 2019). The benefits of cardiac rehabilitation are broad and compelling. One significant problem globally and nationally is the low numbers of eligible patients who enroll in cardiac rehabilitation (Ades et al., 2017; Gardiner et al., 2018; McIntosh et al., 2017; Pio et al., 2019). When patients are advocated for and given education, support, encouragement, motivation, a strong endorsement, and the option to enroll in cardiac rehabilitation, their health can improve dramatically. By choosing to enroll, resulting in the possibility to participate in cardiac rehabilitation, patients may decrease their mortality rate from a cardiac event and improve their quality of life. Individuals improving their health outcomes positively correlate with improving the overall public health status, and healthier people reduce healthcare costs.

\section{Significance of the Practice Problem}

Cardiac rehabilitation is an interprofessional approach to improving the patient's health, emphasizing exercise, stress management, and nutritional education (Mayo Clinic, 2018). This program is a grade $1 \mathrm{~A}$ recommendation for patients admitted to the hospital with cardiac-related 
ICD-10 diagnoses. The American College of Cardiology, American Heart Association, The Agency for Healthcare Research and Quality, and the Centers for Disease Control and Prevention recommend that all patients hospitalized with a cardiac rehabilitation eligible diagnosis should be referred to a cardiac rehabilitation program before hospital discharge (Thomas et al., 2018).

Only $54 \%$ of countries offer cardiac rehabilitation services to their community (Supervia et al., 2019). The staggering CVD statistics force national, regional, and local healthcare organizations to improve the current rate of $12 \%$ to $30 \%$ of patients enrolling in cardiac rehabilitation (Ades et al., 2017). The national benchmark for cardiac rehabilitation participation is $70 \%$, and improving the enrollment rate is one of the first steps to increasing cardiac rehabilitation participation (Ades et al., 2017). The healthcare organization's cardiac rehabilitation enrollment rate before the evidence-based intervention was approximately $13 \%$.

\section{Impact on the Patient}

Cardiac rehabilitation reduced cardiovascular death from $10.4 \%$ to $7.6 \%$ at the 3 -year follow-up (Anderson et al., 2017). Thus, more patients participating in cardiac rehabilitation will decrease cardiac-related fatalities and improve the quality of life (Gardiner et al., 2017; Gardiner et al., 2018). In addition, there is a positive correlation between cardiac rehabilitation and improved patients' biometric results (Gardiner et al., 2017; Graham et al., 2019; Sumner et al., 2017).

\section{Impact on the Healthcare System and Healthcare Cost}

The hospital may reduce the CVD health burden and economic strain by increasing patients attending cardiac rehabilitation. For example, if hospitals can increase cardiac rehabilitation participation from $20 \%$ to $70 \%$, the consequence will be an estimated reduction in 
hospitalizations by 180,000 patients annually (Ades et al., 2017). In 2016, the United States healthcare system spent $\$ 555$ billion on CVD, and by 2035 , the cost is expected to skyrocket to $\$ 1.1$ trillion (CDC, 2015).

Premier benchmark data for CVD outcomes are monitored by the Centers for Medicare and Medicaid Services, which means hospital reimbursement directly correlates with patient outcomes and readmission rates. Cardiac rehabilitation effectively improves the patients' health through guided lifestyle changes reducing the readmission rates for CVD by $4 \%$, which equates to a significant amount of money (Anderson et al., 2016). Currently, the healthcare organization's premier benchmark readmission rates and outcome measurements are no different or worse than the national average (Medicare.gov, 2020). Therefore, the healthcare organization will benefit from increasing the number of patients who enroll and participate in cardiac rehabilitation.

\section{Impact on the Community}

CVD is a priority for community health because it remains the leading cause of death $(\mathrm{Xu}$ et al., 2018). Enrolling $70 \%$ of the eligible patients in cardiac rehabilitation will drastically improve community health (Mayo Clinic, 2018). Patients participating in cardiac rehabilitation will improve individual health resulting in a healthier community (Pio et al., 2019).

\section{PICOT Question}

In patients with isolated coronary artery bypass graft $(\mathrm{CABG})(\mathrm{P})$, how does face-to-face nursing promotion of cardiac rehabilitation (I) compared to the patients who do not have face-toface nursing promotion (C), affect the percentage of patients enrolling in cardiac rehabilitation after discharge $(\mathrm{O})$ within 8 weeks $(\mathrm{T})$ ? 
To align with a healthcare organization's priority project scope, the population was patients admitted with an isolated coronary artery bypass graft (CABG), which referred to using arterial or venous grafts only during surgical intervention (D’Agostino et al., 2019). The population included patients 18 years and older. The healthcare organization performs approximately 50 isolated $\mathrm{CABG}$ surgeries per month.

The intervention was implementing face-to-face nursing promotion of cardiac rehabilitation. The intervention did not focus on patient education; the main objective was to provide strong promotion for the patients to enroll in cardiac rehabilitation. Patient education only occurred during the initial scripted session. Nurses promoted cardiac rehabilitation as the next step in treatment, provided support by addressing concerns, motivated the patients to enroll, advocated by obtaining orders, and guided the patients during the enrollment process. The nurses collaborated with the care managers to reduce identified barriers.

The intervention was compared to the current standard treatment of the healthcare organization, which depended solely on the cardiologist. Retrospective data was collected before the project to determine the percentage of patients enrolled in cardiac rehabilitation compared to the percentage of patients who enrolled after receiving face-to-face nursing promotion.

The goal of face-to-face nursing promotion was to increase the enrollment percentage by $27 \%$ within 8 weeks. The change was expected to be seen quickly since cardiac rehabilitation is started 2-6 weeks after a CABG (Mendes, 2016).

\section{Evidence-Based Practice Framework \& Change Theory}

\section{Johns Hopkins Nursing Evidence-Based Practice Model}

Johns Hopkins Nursing Evidence-Based Practice Model (JHNEBP) guided the evidencebased project. Consistently the literature supports cardiac rehabilitation as an effective treatment 
for CVD (Anderson et al., 2017). The initial evidence-based practice question was how a healthcare organization increases the percentage of patients enrolling in cardiac rehabilitation.

\section{Practice Question}

JHNEBP Question Development Tool guided the interprofessional leadership project team consisting of executive nursing leadership and the project manager to analyze the problem (Dang \& Dearholt, 2017). The team defined the problem as the low number of patients who enroll in cardiac rehabilitation after having an isolated CABG. The evidence-based question was refined to ask what nursing can implement to improve enrollment percentages. The interprofessional team identified stakeholders for the project and individual responsibility using the JHNEBP Stakeholder Analysis Tool (Dang \& Dearholt, 2017).

\section{Evidence}

The interprofessional leadership team collected internal data, and an evidence search strategy included searching various databases to obtain current literature for evidence that improves the practice problem. The literature was appraised using the JHNEBP Evidence Level and Quality Guide (Dang \& Dearholt, 2017). The findings were summarized and synthesized to develop a recommendation to improve the practice problem (Appendix A and B).

\section{Translation}

The healthcare organization is actively trying to increase enrollment rates making the planned evidence-based project appropriate and feasible. The action plan was guided by the JHNEBP Action Planning Tool (Dang \& Dearholt, 2017). The initial plan used nurses from various specialties to educate, support, advocate, promote, motivate, and endorse clients to enroll in cardiac rehabilitation. The healthcare organization was assessed for strengths, weaknesses, barriers, and costs using assessment tools. The evidence-based practice team captured 
dichotomous data if the patient attended the first scheduled cardiac rehabilitation session, obtained a cardiac rehabilitation order, or was active in the enrollment process. Weekly updates were emailed to the stakeholders with relevant information. The project manager monitored the project and made changes as needed. JHNEBP Dissemination Tool guided the sharing of key findings with the stakeholders and professionals interested in the project outcomes.

\section{Stages of Change Theory}

The Stages of Change Theory has become one of the most common theoretical frameworks for medical conditions requiring behavioral changes (Raihan \& Cogburn, 2020). The leading cardiac rehabilitation authority, The American Association of Cardiovascular and Pulmonary Rehabilitation, recommends this theory to guide cardiac rehabilitation (Rohrbach et al., 2017). Cardiac rehabilitation aligns with this theory by supporting patients to make slow changes to their behaviors to improve their health.

The theoretical framework allows the healthcare team to support the patients as they move through six stages. After cardiac surgery, the patients will likely be in the contemplation stage, which means they recognize their choices and behaviors are problematic (Waight et al., 2015). The nurses will encourage and provide a strong endorsement of cardiac rehabilitation by emphasizing the benefits and allow the patients to ask questions and express concerns (York University, n.d.).

If the patients plan to enroll in cardiac rehabilitation, they have progressed to the preparation stage. The patients believe that their behavior and actions will improve their health outcomes (Krebs et al., 2020). During this phase, the healthcare team will provide motivation, positive reinforcement, and support (York University, n.d.). 


\section{Evidence Search Strategy}

An electronic search of the EBSCO digital database was conducted using the University of St. Augustine's (USA) library. The multiple database search included 34 research articles from Cumulative Index to Nursing and Allied Health Literature (CINAHL), one research article from Cochrane Library of Systematic Reviews, 59 research articles from Gale Academic OneFile, 30 research articles from Medline, eight research articles from Academic Search Index, and five research articles from SPORTDiscus, which resulted in 137 research articles. The keywords using Boolean operators for the evidence search included cardiac rehab* (select a field: in the title) AND nurs* AND enrollment or utilization or utilisation. The search was narrowed by adding exclusion criteria NOT outpatient clinics or ambulatory care or outpatient services or outpatient care and NOT pediatrics. The initial search used keywords cardiac rehab* AND nurs* AND enrollment, which yielded 10 research articles requiring the search to be widened. Other unsuccessful searches included keywords face-to-face promotion and nurs* interventions. The British spelling of utilisation was included since many research articles are international. The search was not limited to $\mathrm{CABG}$ patients since this niche population was requested by hospital administration to fit a current project scope. The advance search options were limited to timeframe: 2015-2021, language: English, report type: full-text, peer-reviewed, and academic journals. The USA database search engine removed duplicate research articles.

\section{Evidence Search Results}

Even though the articles followed the search criteria, many of the research articles identified did not apply to the PICOT. Titles and abstracts of 137 articles were reviewed for PICOT relevance, which focused on increasing cardiac rehabilitation enrollment rates utilizing face-to-face nursing promotion. Eighty-eight articles were excluded for various reasons. 
Exclusion criteria included a research goal to solve patient barriers to enrollment, interventions to improve the referral and implementation of cardiac rehabilitation, and interventions to increase patient adherence and participation. The research articles that focused on increasing enrollment numbers into cardiac rehabilitation were excluded if the articles concentrated on patient-provider interaction, patient's perception about enrollment, clinical practice guidelines, interventions included mobile apps or telemedicine, and enrollment was for cardiac rehabilitation phase I. A full-text survey of the remaining 49 articles was conducted to locate the best research articles supporting increasing cardiac rehabilitation enrollment using face-to-face nursing promotion. The full-text survey resulted in a final number of seven primary research studies and one systematic review with meta-analysis summarized using a PRISMA figure located in Figure 1.

Each of the seven articles was appraised for its strength using the evidence level and quality grading based on the JHNEBP guide (Dang \& Dearholt, 2017). The seven articles ranged in evidence levels from level I through level III. Four of the articles were experimental randomized control trials (RCT), resulting in an evidence level I (Ali-Faisal et al., 2016; Cossette et al., 2012; Grossman, 2015; Scott et al., 2013). The systematic review with meta-analysis (Pio et al., 2019) and a mixed-method study resulting in standardized online provider education specific to cardiac rehabilitation enrollment (Santiago de Araújo Pio et al., 2020b) are categorized as evidence level II. Ades et al. (2017) meta-synthesis was a significant catalyst for the healthcare system to focus on improving enrollment rates into cardiac rehabilitation is classified as level III. Table 1 provides a summary of the JHNEBP criteria for each evidence level. 
All seven of the quantitative research articles are rated high quality based on the JHNEBP quality rating. Each quantitative article demonstrated consistent results, adequate sample size, appropriate controls, and conclusions consistent with other research studies of similar focus (Dang \& Dearholt, 2017). A separate table was created for the primary research articles’ evidence search results and systematic review located in Appendices A and B.

\section{Themes with Practice Recommendations}

The themes were determined after a thorough investigation and synthesis of each article listed in the evidence table (Appendices A and B). The research article's participants all had a cardiac rehabilitation eligible diagnosis, but the admitting diagnoses varied among the studies but did not impact the conclusions about increasing cardiac rehabilitation enrollment. The type of medical unit the patients received care on did impact the enrollment rate into cardiac rehabilitation (Ali-Faisal et al., 2016). High-quality research was conducted in numerous countries, which did not impact the interventions that increase enrollment rates.

\section{Themes}

The themes synthesized from the articles include developing a systematic approach for cardiac rehabilitation enrollment (Ades et al., 2017; Santiago de Araujo Pio et al., 2020b), faceto-face promotion (Ades et al., 2017, Cossette et al., 2012; Grossman, 2015; Santiago de Araujo Pio et al., 2020b; Scott et al., 2013; Pio et al., 2019), lack of education among the healthcare team (Ali-Faisal et al., 2016; Santiago de Araujo Pio et al., 2020b; Pio et al., 2019), and patient barriers that impede enrollment (Cossette et al., 2012; Scott et al., 2013).

\section{Healthcare Organization Systematic Process}

The literature strongly advocates for healthcare organizations to start with a systematic approach for cardiac rehabilitation enrollment to streamline communication, reduce ambiguity, 
and coordinate roles among the healthcare team (Ades et al., 2017). The enrollment strategy

should include standardized staff and patient education using a script to improve the accuracy of the patients' message (Ades et al., 2017; Santiago de Araujo Pio et al., 2020b).

\section{Face-to-Face Cardiac Rehabilitation Promotion}

Strong evidence supports that patients who receive cardiac rehabilitation promotion via face-to-face communication correlates with increased enrollment rates. A discrepancy noticed among the literature is which member of the healthcare team should complete face-to-face promotion. A physician endorsement has the most significant impact on enrollment (Ades et al., 2017); however, the nurse's endorsement is meaningful and impactful (Cosette et al., 2012; Grossman et al., 2015; Pio et al., 2019). Nursing face-to-face promotion is supported by substantial evidence as the ideal intervention to increase enrollment rates by an average of $27 \%$ (Cosette et al., 2012; Grossman, 2015, Pio et al., 2019). Face-to-face promotion was also successful with using an allied health member functioning in a patient navigator's role to promote, encourage, educate, advocate, motivate, and guide the patient through the enrollment process (Ades et al., 2017; Scott et al., 2013). Cardiac rehabilitation promotion includes education, a strong endorsement, support, motivation, and encouragement, and provides an opportunity to ask questions, advocate, initiate the enrollment process, and disseminate printed patient informational handouts (Ades et al., 2017; Santiago de Araujo Pio et al., 2020b).

\section{Lack of Healthcare Provider Cardiac Rehabilitation Knowledge}

According to Schopher et al. (2016), 72\% of healthcare providers lack knowledge about cardiac rehabilitation. The healthcare team's lack of knowledge leads to inaccurate and insufficient patient education, advocacy, promotion, encouragement, and support resulting in a failure to enroll in cardiac rehabilitation (Ades et al., 2017; Ali-Faisal et al., 2016). After the 
healthcare providers receive education, they report a positive attitude about cardiac rehabilitation and are more likely to promote it to their patients (Santiago de Araujo Pio et al., 2020b). The healthcare team should use available educational tools endorsed by cardiac rehabilitation experts to improve their knowledge about benefits, promotion techniques, resources, and outcomes (Pio et al., 2019; Santiago de Araujo Pio et al., 2020b).

\section{Address Patient Barriers to Enrollment}

Patients face barriers to participating in cardiac rehabilitation that decreases enrollment rates, which will logically increase if the barriers are addressed. Common barriers identified in the literature include the distance to the location of the cardiac rehabilitation center (Ali-Faisal et al., 2016; Cossette et al., 2012), transportation (Cosette et al., 2012), cost (Scott et al., 2013), and lack of education (Ades et al., 2017; Santiago de Araujo Pio et al., 2020b). The enrollment strategy will need to include the care management team members to address and attempt to solve the patients' barriers that hinder enrollment. Face-to-face nursing promotion will improve the lack of knowledge.

\section{Recommendation}

The evidence was obtained from seven high-quality, evidence level I-III primary research articles with consistent outcomes. The recommendation is based on the thorough and rigorous review of the synthesized information and summarized in Figure 2. The first step was the healthcare organization developing a systematic approach focusing on the cardiac rehabilitation enrollment strategy. Face-to-face promotion consistently remains the best practice to increase enrollment rates; thus, the recommendation was to have the nurses implementing face-to-face promotion. Nurses are interacting with clients frequently, so face-to-face promotion was easily embedded into their current workflow. Instead of engaging the physicians, which is difficult, the 
recommendation was to include cardiac rehabilitation face-to-face promotion from the nurse practitioners (ARNP). The recommendation included the care managers to communicate with the patients about barriers and find possible solutions. Before the nursing face-to-face promotion begins, the recommendation was the nurses receive standardized education about cardiac rehabilitation and promotion.

\section{Setting, Stakeholders, and Systems Change}

The healthcare organization is a 2,247-bed Christian-based, non-profit hospital providing comprehensive medical services to Central Florida patients. The mission is to extend Christ's healing ministry through whole-person care addressing the mind, body, and spirit. The hospital provides cardiovascular care to 72,000 patients each year treated by a team of more than 1,000 specially trained healthcare providers. The pilot unit will be Ginsberg Tower (GT) 8, cardiovascular surgery progressive care unit.

In January 2020, the executive leadership team focused on cardiac rehabilitation low enrollment rates, making it an organizational project scope for 2020-2025. Face-to-face nursing promotion of cardiac rehabilitation perfectly aligned with the project scope. The PICOT and recommendations were strongly supported by the chief nursing officer, executive director of cardiovascular services, nursing director of cardiovascular services, and cardiac rehabilitation nurse manager. These key stakeholders strongly advocated for participation from other stakeholders, including GT8 nurse manager, nursing education, clinical data analyst, institutional outcome and value analyst, executive director of clinical outcomes, registered nurses, cardiovascular surgical ARNPs, cardiac rehabilitation care coordinators, care managers, and a patient representative. 
The interprofessional collaboration occurred between the GT8 registered nurses, cardiovascular surgical ARNPs, care managers, cardiac rehabilitation care coordinators, discharge nurses, data abstractors, and data analysts. The project remained net-neutral; thus, the interventions were embedded in the caregivers' current workflows to maintain sustainability.

The SWOT analysis was discussed with key stakeholders regarding the organization's ability to implement the project (Figure 3). The strengths included considerable resources and leadership support to implement and sustain change. The weaknesses included resistance to change, staff fatigue, and burnout due to COVID-19. The opportunity was improved outcomes and increased reimbursement. The threats included increase workload, RN turnover, and changes in payors.

The micro-level system changes included purposeful interactions and patient empowerment, which were currently undervalued. The change consisted of the daily clinical practice of providing isolated CABG patients with endorsement, education, encouragement, motivation, support, advocacy, and tools to enroll in cardiac rehabilitation. The project provided purposeful, meaningful, and high-quality interactions during face-to-face promotion, which allowed the patients to ask questions in a supportive environment empowering the patients to make informed decisions about their health.

Changes to the system at the meso-level improved the nurses' lack of cardiac rehabilitation knowledge, which resulted in inconsistent patient education, endorsement, encouragement, support, and reduced enrollment in cardiac rehabilitation. The system change involved educating the nurses about cardiac rehabilitation, tools, techniques, and the new systematic process to increase enrollment rates. 
The macro-level system change focused on the intersectoral links that are overlooked. Numerous team members attempted to improve low enrollment rates; however, they worked in silos. There was no feedback loop and communication among the team resulting in gaps and inconsistent information given to the patients. The system change developed an integrated process of coordination of roles to reduce duplication, provide consistent information, and improve interprofessional communication.

\section{Implementation Plan with Timeline and Budget}

The project team utilized the JHNEBP model to determine the project question and an evidence-based solution. There was sufficient internal data to support the need to increase the current cardiac rehabilitation enrollment rate, and high-quality literature supported nursing faceto-face cardiac rehabilitation promotion would be beneficial. The activities' schedule is listed in a Gantt chart that provides detailed steps with the timing of the intervention and evaluation process (Appendix C).

The objective that determined the project's impact was the cardiac rehabilitation enrollment rate of patients with isolated $\mathrm{CABG}$ admitted to the pilot unit would increase by $27 \%$ 8 weeks after implementing face-to-face nursing promotion. Due to time constraints, enrollment was measured by the patients who obtained an order for cardiac rehabilitation from their provider, active in the enrollment process, or attended their first scheduled cardiac rehabilitation session. The objective was met through system change by empowering the patients through purposeful and meaningful face-to-face nursing promotion, educating the nurses to become cardiac rehabilitation experts to promote enrollment, and creating a systematic collaboration process among the interprofessional team. 
A systematic process was developed and implemented to improve coordination among the intersectoral links, improve interprofessional team communication, and designate clear roles. After completing a SWOT analysis and key stakeholder assessments, a process was developed. The systematic approach is described in Figure 4.

The nurses and care managers worked together to address a different aspect of cardiac rehabilitation promotion. They shared the patient status specific to their focus during the daily interprofessional collaboration (IPC) rounds on the pilot unit to improve communication, continuity of care, and collaboration. The interprofessional team collaboration checklist facilitated communication and held team members accountable for compliance using face validity (Appendix D).

The healthcare organization meso-level system change addressed the evidence theme that healthcare providers lack education about cardiac rehabilitation. The objective was $90 \%$ of the nurses will demonstrate an understanding of cardiac rehabilitation, benefits, the enrollment process, and face-to-face promotion with patients who have an isolated CABG within 2 weeks after receiving standardized education. The objective was met by providing nurses with standardized education based on the International Council of Cardiovascular Prevention and Rehabilitation (ICCPR) (York University, n.d.). After educating the nurses, they took a post-test and needed to score a minimum of $90 \%$ to be considered successful.

An objective focused on standardized face-to-face nursing promotion among the CR champions. Within 8 weeks of implementing the project, $90 \%$ of the CR champion's initial faceto-face nursing promotion sessions followed the defined process. The initial face-to-face promotion included the CR champions using a script (Appendix E), providing an iPad for the patient to watch an informational video about cardiac rehabilitation called Cardiac 
rehabilitation: Your journey back to heart health (CardioSmart, 2016), and delivering the cardiac rehabilitation promotion packet (Appendix F). This process supported the patients in the Stages of Change Theory's contemplation stage by providing the benefits of cardiac rehabilitation, answering questions, and addressing concerns. The objective was met because the CR champions received education and the tools required.

The patients admitted with an isolated $\mathrm{CABG}$ received face-to-face nursing promotion by nurses in various specialty roles. Of the patients who had an isolated CABG on GT8, 90\% would receive face-to-face cardiac rehabilitation nursing promotion from the CR champions, staff nurses, cardiovascular surgical ARNPs, and discharge nurses, including having barriers addressed by the care managers 8 weeks after implementation of the project. This objective was met because of the systematic process in place, cardiac rehabilitation education, interprofessional team collaboration, and nurses did have the required tools to promote cardiac rehabilitation. The role of each team member is described in Figure 4.

The healthcare organization did not provide a project budget forcing the project to remain net-neutral (Table 2). Embedding the intervention into the current workflows helped keep the project net-neutral and increased sustainability. The project manager received a grant to cover the cost of patient educational material and a statistician.

The project manager supported the interprofessional team, collected data, provided weekly communication with the stakeholders, adjusted the project as needed based on limitations and ethical concerns, and monitored compliance with surveillance and electronic health record documentation review. Leadership qualities and skills included promoting a positive work environment, empowering the team, demonstrating openness for new ideas, incorporating opinions for changes, and fostering a sense of team. 
After a thorough risk assessment, the key stakeholders and project manager determined a low risk for patient harm in correlation with the evidence-based project. Cardiac rehabilitation has inherent risks, but these risks did not apply to face-to-face nursing promotion and enrollment. Other areas of risk included staff noncompliance, obtaining timely data, and budget. The strategy to address noncompliance and budget risks was mitigation. The elimination strategy was used to manage the risk with delayed data dissemination. The healthcare organization owns the cardiac rehabilitation center, and an increase in participation will increase revenue, which was a conflict of interest.

\section{Evaluation Results}

After approval from the University of St. Augustine's EBP Project Review Council (EPRC) and the executive leadership team at the healthcare organization, the implementation and evaluation process began. The participants included patients on GT8, status post isolated CABG. Appendix $\mathrm{G}$ explained the type of data collected, who collected it, which statistical tools were used per data measurement, the frequency of data collection, where the data was accessed, categorical measures, and benchmarks.

The interprofessional team member's roles (Figure 4), interprofessional collaboration, data collection tool (Appendix H), and interprofessional team collaboration checklist (Appendix D) maintained the integrity of the data collection process. The data collection resources were valid and reliable since the data came from project manager surveillance, interprofessional team member documentation in the electronic health record, and information from the health information management system. Listwise deletion was used to deal with missing data so that only data with all observations were used for every analysis. The project team set a limit of 5\% missing data was acceptable before corrective action. The data collected that contained personal 
health information was stored on the healthcare organization's encrypted, HIPAA compliant share-drive.

A statistician used descriptive and inferential statistics to determine the impact of face-toface nursing promotion of cardiac rehabilitation on cardiac rehabilitation enrollment. Descriptive statistics measured different variables such as enrollment rate, impact enrollment rate into cardiac rehabilitation, barriers resolved, face-to-face promotion, nurse cardiac rehabilitation education, and nursing face-to-face promotion compliance. Inferential statistics assessed the associations among variables. The chi-square tests were used to test the associations among categorical dependent and categorical independent variables. Independent sample $t$-tests were used to assess whether statistically significant associations exist between continuous dependent and categorical independent variables. Variations were considered statistically significant at $p<$ 0.05 .

There were $N=73$ patients in the sample whose age ranged from 38 to 88 years $(M=$ 64.35, $S D=10.57)$ and included $53(72.6 \%)$ males and $20(27.4 \%)$ females and most patients had Medicare, 42 (57.5\%) (Table 3). There were 67 (91.8\%) patients that received face-to-face nursing promotion by the cardiac rehabilitation champion and six $(8.2 \%)$ did not receive it (Table 4). There were $21(28.8 \%)$ patients that enrolled in cardiac rehabilitation, $28(38.4 \%)$ did not, and $24(32.9 \%)$ were not candidates (Table 5). A cross-tabulation of cardiac rehabilitation enrollment of face-to-face nursing promotion was conducted. Out of 45 cardiac rehabilitation eligible patients that received face-to-face nursing promotion, $19(42.2 \%)$ enrolled in cardiac rehabilitation, whereas $26(57.8 \%)$ did not enroll (Table 6). These results were not statistically significant, $\chi 2(1)=0.091, p=.763$ (Table 7). However, this data is clinically significant because, 
among cardiac rehabilitation eligible clients, face-to-face promotion increased the enrollment rate by $29 \%$.

Results of the project did not show a statistically significant association between face-toface nursing promotion and cardiac rehabilitation enrollment. A factor that may have influenced the results was that of sample size. The sample size required to achieve $80 \%$ statistical power was at least 88 , based on a $\mathrm{G}^{*}$ Power sample size calculations (Figure 5). This reduced sample size in this project resulted in lower statistical power, which may have affected the results.

However, there was an overall increase of $16 \%$ in cardiac rehabilitation enrollment (21 clients enrolled out of 73) after the project compared to the $13 \%$ initial enrollment rate, which is clinically significant. Clinical significance was determined using descriptive data to assess the impact on the current processes and outcomes. Supplementary analysis was conducted to determine if there were significant associations between cardiac rehabilitation enrollment with ARNP endorsement, GT8 RN support, discharge nurse endorsement, and care manager assistance with overcoming barriers. Chi-square tests were conducted to test these associations. Regarding ARNP endorsement, there was no statistically significant association with enrollment, $\chi 2(1)=2.457, p=.117$. Within those enrolled, there were $13(61.9 \%)$ with ARNP endorsement versus those with non-ARNP endorsement, (eight, 38.1\%) (Tables 8 and 9). There was more enrollment with ARNP endorsement, which is clinically significant. Regarding the association between cardiac rehabilitation enrollment and GT8 registered nurse support, results of the chi-square test revealed no statistically significant association, $\chi 2(1)=0.791, p=.374$ (Tables 10 and 11); however, the low GT8 RN compliance rate of 22\% was clinically significant. Regarding the association between cardiac rehabilitation enrollment and discharge nurse endorsement, results of the chi-square test revealed no significant results, $\chi 2(1)=0.244, p=$ 
.621. The proportion of discharge nurse endorsement in both cardiac rehabilitation enrollment and non-enrollment was similar (Tables 12 and 13). Regarding the association between enrollment and patient barriers, there was a statistically significant association, $\chi 2(6)=12.519$, $p=.021$ (Table 14). One noticeable feature is that, within non-enrollment, the location was the most frequent barrier. In the cardiac rehabilitation enrollment group, most clients denied having any barriers to cardiac rehabilitation enrollment. Removing barriers may increase cardiac rehabilitation enrollment, which is clinically significant.

\section{Impact}

The evidence-based project provided a systematic process that addressed gaps within the healthcare organization by implementing change at various system levels. The evidence-based project improved the gap of general knowledge about cardiac rehabilitation among most healthcare providers. The project incorporated the interprofessional team to work in tandem with clear roles and enhanced communication, increasing cardiac rehabilitation enrollment rates among isolated $\mathrm{CABG}$ patients by $16 \%$. The interprofessional team members are now providing consistent cardiac rehabilitation promotion that has reduced the gaps in information and education the clients receive.

Future implications of the project involve providing face-to-face nursing promotion to all patients admitted with eligible cardiac rehabilitation ICD-10 diagnoses. The healthcare organization will need to budget for an increase in the number of nurses who will function in the cardiac rehabilitation champions' role to provide a strong, scripted initial face-to-face promotion. The healthcare organization can anticipate reducing cardiac-related readmissions and a reduced cost in treating cardiovascular disease as the percentage of cardiac rehabilitation enrollment continues to increase. 
To improve practice in the future will require continuous education of the healthcare team about cardiac rehabilitation, the benefits, and the healthcare organization's cardiac rehabilitation enrollment process. The cardiac rehabilitation care coordinators will need to dedicate a minimum of one patient encounter specific for cardiac rehabilitation to provide a purposeful, client empowering session that remains scripted. The nurse practitioners will need to continue to endorse cardiac rehabilitation during rounds. Finally, the healthcare organization will need to dedicate resources to reducing barriers to enrolling in cardiac rehabilitation.

The cardiac rehabilitation department will need to provide surveillance to ensure compliance of the cardiac rehabilitation champions and nurse practitioners. The health information management team will continue to collect data about cardiac rehabilitation enrollment rates to determine if the project remains effective. Identified barriers that impacted the project's outcomes that will need to be addressed include the continual use of float nurses with limited education about cardiac rehabilitation, minimal support by physicians, and lack of authority to hold the ARNPs accountable.

\section{Dissemination Plan}

Dissemination of the project results will be presented to the project stakeholders, allowing the nurses and case managers to see their impact and provide a feedback loop. There will be another presentation for the healthcare organization's executive board during their monthly meeting, sharing the project's clinical significance and the impact on the organization's project scope to increase enrollment rates into cardiac rehabilitation. Due to the COVID-19 pandemic, the presentations will be conducted virtually by sharing the information via a PowerPoint presentation. The presentation will be recorded and shared with healthcare professionals interested in the clinical significance of the project and its impact on the problem. 
A poster presentation will be given at the annual Chi Upsilon Chapter of Sigma research day (November 2021) and the American Association of Cardiovascular and Pulmonary Rehabilitation (AACVPR) annual conference (October 2021). A manuscript of the evidencedbased project and outcomes will be submitted to the Journal of Cardiopulmonary Rehabilitation and Prevention (JCPR). JCPR is chosen because it is a peer-reviewed professional journal dedicated to improving multidisciplinary clinical practice and expanding research evidence specific to cardiac rehabilitation. JCPR is the official journal of the AACVPR, which remains the leading expert on cardiac rehabilitation. Before submitting an abstract, manuscripts, and poster presentations, the information will be peer-reviewed for accuracy, validity, strengths, weaknesses, and quality. The peer reviewers will be scholarly experts in the field of cardiac rehabilitation. The evidence-based project manuscript will be published in SOAR@USA.

\section{Conclusion}

Based on a thorough investigation and synthesis of high-quality research articles, the evidence-based project utilized an interprofessional approach of nursing face-to-face promotion of cardiac rehabilitation for patients admitted with an isolated CABG to increase cardiac rehabilitation enrollment rates by $27 \%$. The project resulted in a $16 \%$ cardiac rehabilitation enrollment increase. Face-to-face promotion, ARNP endorsement, and reducing barriers were clinically significant in increasing the enrollment rate.

The evidence-based project was guided by the John Hopkins Nursing Evidence-Based Model, the Stages of Change Theory, and the healthcare organization's needs, resulting in system changes occurring at various levels. Themes synthesized from the research articles include developing a systematic approach for cardiac rehabilitation enrollment, educating the nurses about cardiac rehabilitation, reducing patient barriers to enrollment, and providing face- 
to-face nursing promotion of cardiac rehabilitation, which the project incorporated. Each interprofessional team member had a role-specific to their current workload to promote face-toface nursing promotion of cardiac rehabilitation and reduce barriers with collaboration that addressed each patient's individualized needs to promote cardiac rehabilitation enrollment. 


\section{References}

Ades, P., Keteyian, S., Wright, J., Hamm, L., Lui, K., \& Newlin, L. (2017). Increasing cardiac rehabilitation participation from $20 \%$ to $70 \%$ : A road map from the million hearts cardiac rehabilitation collaborative. Mayo Clinic Proceedings, 92(2). 234-245. http://dx.doi.org/10.1016/j.mayocp.2014.10.014

Ali-Faisal, S. F., Benz Scott, L., Johnston, L., \& Grace, S. L. (2016). Cardiac rehabilitation referral and enrolment across an academic health sciences centre with e-referral and peer navigation: A randomized controlled pilot trial. BMJ Open, 6(3), e010214. https://doi.org/10.1136/bmjopen-2015-010214

American Heart Association. (2019). Heart disease and stroke statistics-2019 at-a-glance. Retrieved from https://healthmetrics.heart.org/wp-content/uploads/2019/02/At-A-Glance$\underline{\text { Heart-Disease-and-Stroke-Statistics-\%E2\%80\%93-2019.pdf }}$

American Association of Cardiovascular and Pulmonary Rehabilitation (AACVPR). (n.d.). Resources for patients. Retrieved from https://www.aacvpr.org/Portals/0/Docs/Practice/AACVPR_CR_Fact_Sheet.pdf

Anderson, L., Oldridge, N., Thompson, D., Zwisler, A., Rees, K., Martin, N., \& Taylor, R. (2016). Exercised-based cardiac rehabilitation for coronary heart disease: Cochran Systematic Review and meta-analysis. Journal of the American College of Cardiology, 67(1), 1-12. http://dx.doi.org/10.1016/j.jacc.015.10.044-

Benjamin, E., Munter, P., Alonso, A., Bittencourt, M., \& Virani, S. (2019). Heart disease and stroke statistics_-2019 update: A report from the American Heart Association. Circulation, 139(10), 23-56. http://dx.doi.org/10.1161/CIR.0000000000000659 
CardioSmart. (2016, May 13). Cardiac rehabilitation: Your journey back to heart health

[Video]. YouTube. https://www.youtube.com/watch?v=ckOHA4zSHr0

Centers for Disease Control and Prevention. (2020). Advocacy. Retrieved from https://www.heart.org/idc/groups/ahaeccpublic/@wcm/@adv/documents/downloadable/ucm_473083.pdf

Cossette, S., Frasure-Smith, N., Dupuis, J., Juneau, M., \& Guertin, M. (2012). Randomized controlled trial of tailored nursing interventions to improve cardiac rehabilitation enrollment. Nursing Research, 61(2), 111-120. https://doi.org/10.1097/nnr.0b013e318240dc6b

D’Agostino, R., Jacobs, J., Badhwar, V., Fernandez, F. G., Paone, G., Wormuth, D., \& Shahian, D. (2019). The Society of Thoracic Surgeons adult cardiac surgery database: 2019 update on outcomes and quality. The Annals of Thoracic Surgery, 107(1), 24-32. https://doi.org/10.1016/j.athoracsur.2018.10.004

Dang, D., \& Dearholt, S. (2017). Johns Hopkins nursing evidence-based practice: model and guidelines. 3rd ed. Indianapolis, IN: Sigma Theta Tau International

Gardiner, F., Nwose, E., Ragan, E., Park, B., Bwitit, P., Crockett, J., \& Wang, L. (2018). Outpatient cardiac rehabilitation: Patient perceived benefits and reasons for nonattendance. Collegian, 25, 479-485. https://doi.org/10.1016/j.colegn.2018.01.001

Gardiner, F., Regan, E., Nwose, E., Bwititi, P., Crockett, J., \& Wang, L. (2017). Outpatient cardiac rehabilitation: Effects on patient improvement outcomes. Diabetes and Metabolic Syndrome: Clinical Research and Reviews, 11, 1025-1030. http://dx.doi.org/10.1016/j.dsx.2017.07.034 
Graham, H., Lac, A., Lee, H., \& Benton, M. (2019). Predicting long-term mortality, morbidity, and survival outcomes following a cardiac event: A cardiac rehabilitation study. Rehabilitation Process and Outcomes, 8, 1-8. http://dx.doi.org/10/1177/1179572719827610

Grossman, J. (2015). Cardiac rehabilitation enrollment and the impact of systematic nursing interventions for postmyocardial infarction and stent patients. Clinical Nursing Research, 25(4), 378-390. https://doi.org/10.1177/1054773815620777

Krebs, P., Norcross, J. C., Nicholson, J., \& Prochaska, J. (2018). Stages of change and psychotherapy outcomes: A review and meta-analysis. Journal of Clinical Psychology, 74(11), 1964-1979. https://doi.org/10.1002/jclp.22683

Mayo Clinic. (2018). Heart disease: Diagnosis and treatment. Retrieved from https://www.mayoclinic.org/diseases-conditions/heart-disease/diagnosis-treatment/drc$\underline{20353124}$

Medicare.gov (2020). Hospital compare. Retrieved from https://www.medicare.gov/hospitalcompare/profile.html\#profTab=4\&ID=100007\&cmprI $\underline{D}=100007 \&$ dist $=25 \&$ loc $=32803 \&$ lat $=28.5542151 \& \operatorname{lng}=-$

\section{$\underline{81.3454417 \& \mathrm{cmprDist}=2.6 \& \operatorname{Distn}=2.6}$}

Mendes, M. (2016). Is there a role for cardiac rehabilitation after coronary artery bypass grafting? Circulation, 133(24), 2538-2543. https://doi.org/10.1161/circulationaha.115.017800

McIntosh, N., Charns, M., Fix, G., McDonald, S., Kelly, A., Forman, D., \& Manning, K. (2017). A qualitative study of participation in cardiac rehabilitation programs in an integrated 
health care system. Military Medicine, 182(9), 1757-1763. http://dx.doi.org/10.7205/MILMED-D-17-00053

Moher, D., Liberati, A., Tetzlaff, J., \& Altman, D.: The PRISMA Group (2009). Preferred reporting items for systematic reviews and meta-analyses: The PRISMA Statement. PLoS Med 6(7): e1000097. https://doi.org/10.1371/journal.pmed.1000097

Pio, C., Chaves, G., Davies, P., Taylor, R., \& Grace, S. (2019). Interventions to promote patient utilization of cardiac rehabilitation: Cochrane systematic review and meta-analysis. Journal of Clinical Medicine, 8(2), 189-208. https://doi.org/10.3390/jcm8020189

Raihan, N. \& Cogburn, M. (2020). Stages of Change Theory. StatPearls [Internet]. StatPearls Publishing. Retrieved from https://www.ncbi.nlm.nih.gov/books/NBK556005/

Rohrbach, G., Schopfer, D., Krishnamurthi, N., Pabst, M., Bettencourt, M., Loomis, J., \& Whooley, M. (2017). The design and implementation of a home-based cardiac rehabilitation program. Federal Practitioner, 34(5), 34-39. Retrieved from https://www.ncbi.nlm.nih.gov/pmc/articles/PMC6370433/

Santiago de Araújo Pio, C., Beckie, T. M., Varnfield, M., Sarrafzadegan, N., Babu, A. S., Baidya, S., Buckley, J., Chen, S.-Y., Gagliardi, A., Heine, M., Khiong, J., Mola, A., Radi, B., Supervia, M., Trani, M. R., Abreu, A., Sawdon, J. A., Moffatt, P. D., \& Grace, S. L. (2020a). Promoting patient utilization of outpatient cardiac rehabilitation: A joint international council and Canadian association of cardiovascular prevention and rehabilitation position statement. International Journal of Cardiology, 298, 1-7. https://doi.org/10.1016/j.ijcard.2019.06.064

Santiago de Araújo Pio, C., Gagliardi, A., Suskin, N., Ahmad, F., \& Grace, S. (2020b). Implementing recommendations for inpatient healthcare provider encouragement of 
cardiac rehabilitation participation: Development and evaluation of an online course. BMC Health Services Research, 20(1). 1-13. https://doi.org/10.1186/s12913-020-05619-2

Schopfer, D., Priano, S., Allsup, K., Helfrich, C., Ho, P., Rumsfeld, J., Forman, D., \& Whooley, M. (2016). Factors associated with utilization of cardiac rehabilitation among patients with ischemic heart disease in the veterans' health administration. Journal of Cardiopulmonary Rehabilitation and Prevention, 36(3), 167-173. https://doi.org/10.1097/hcr.0000000000000166

Scott, L., Gravely, S., Sexton, T., Brzostek, S., \& Brown, D. (2013). Examining the effect of a patient navigation intervention on outpatient cardiac rehabilitation awareness and enrollment. Journal of Cardiopulmonary Rehabilitation and Prevention, 33(5), 281-291. https://doi.org/10.1097/hcr.0b013e3182972dd6

Sumner, J., Harrison, A., \& Daugherty, P. (2017). The effectiveness of modern cardiac rehabilitation: A systematic review of recent observational studies in non-attenders versus attenders. PLoSOne, 12(5), 1-4. http://dx.doi.org/10.1371/journal.pone.0177658

Supervia, M., Turk-Adawi, K., Lopez, F., Pesah, E., Ding, R., \& Britto, R. (2019). Nature of cardiac rehabilitation around the globe. EClinicalMedicine, 13, 46-56. http://dx.doi.org/10.1016/j.eclinm.2019.06.006

The Centers for Disease Control and Prevention (CDC). (2015). Heart disease and stroke cost America nearly $\$ 1$ billion a day in medical costs and lost productivity. Retrieved from https://www.cdcfoundation.org/pr/2015/heart-disease-and-stroke-cost-america-nearly-1billion-day-medical-costs-lost-productivity

Thomas, R., Balady, G., Banka, G., Beckie, T., Chiu, J., Gokak, S., Ho, P., Keteyian, S., King, M., Lui, K., Pack, Q., Sanderson, B., \& Wang, T. (2018). 2018 ACC/AHA clinical 
performance and quality measures for cardiac rehabilitation: A report of the American College of Cardiology/American Heart Association task force on performance measures. Circulation: Cardiovascular Quality and Outcomes, 11(4), 1814-1837. https://doi.org/10.1161/hcq.0000000000000037

Waight, C. A., Strodl, E., Sheridan, J., \& Tesar, P. (2015). Posttraumatic growth in post-surgical coronary artery bypass graft patients. Health Psychology Open, 2(1), 1-9. https://doi.org/10.1177/2055102915571370

Xu, J., Murphey, S., Kochanek, K., Bastian, B., \& Arias, E. (2018). Deaths: Final data. National Vital Statistics Report, 67(5). Retrieved from https://www.cdc.gov/nchs/data/nvsr67/nvsr67_05.pdf

York University. (n.d.) Tools to promote cardiac rehabilitation utilization. Retrieved from https://sgrace.info.yorku.ca/tools-to-promote-cardiac-rehabilitation-utilization/ 
Table 1.

John Hopkins Nursing Evidence-Based Practice Evidence Level

Evidence Description

Level

Level I Experimental study, randomized controlled trial (RCT)

Systematic review of RCTs, with or without meta-analysis

Level II Quasi-experimental study

Systematic review of a combination of RCTs and quasi-experimental

Quasi-experimental studies, with or without meta-analysis

Level III Non-experimental study

Systematic review of a combination of RCTs, quasi-experimental, non-

experimental, non-experimental studies only, with or without meta-analysis

Qualitative study or systematic review, with or without meta-analysis

Level IV Opinion of respected authorities, nationally recognized expert committees, consensus panels based on scientific evidence

Level V Based on experiential and non-research

evidence

(Dang \& Dearholt, 2017)

Note. Johns Hopkins Nursing Evidence-Based Practice evidence level guide 
Table 2.

Budget

\begin{tabular}{|c|r|l|r|}
\hline EXPENSES & & REVENUE & \\
\hline Direct & & Billing & $\$ 0$ \\
\hline Salary and benefits & $\$ 0$ & Grants & $\$ 2500$ \\
\hline Supplies & & & \\
\hline (print patient information material) & $\$ 275$ & Institutional budget support & \\
\hline Services & $\$ 0$ & Cardiovascular discharge plan budget & $\$ 0$ \\
\hline Statistician & $\$ 2200$ & & \\
\hline Indirect & $\$ 0$ & & $\$ 25$ \\
\hline Overhead & $\$ 0$ & & \\
\hline (net-neutral intervention) & & & \\
\hline & & & \\
\hline & & & \\
\hline
\end{tabular}


Table 3.

Patient Demographics

\begin{tabular}{|c|c|c|c|c|}
\hline Variable & $M$ & $S D$ & $n$ & $\%$ \\
\hline Age & 64.35 & 10.57 & & \\
\hline \multicolumn{5}{|l|}{ Gender } \\
\hline Males & & & 53 & 72.6 \\
\hline Females & & & 20 & 27.4 \\
\hline \multicolumn{5}{|l|}{ Insurance } \\
\hline Medicare & & & 42 & 57.5 \\
\hline Private & & & 25 & 34.2 \\
\hline Medicaid & & & 2 & 2.7 \\
\hline Government & & & 2 & 2.7 \\
\hline Not insured & & & 2 & 2.7 \\
\hline
\end{tabular}


Table 4.

Face-to-Face Nursing Promotion Compliance

\begin{tabular}{lcc}
\hline Variable & Frequency & Percent \\
\hline no & 6 & 8.2 \\
yes & 67 & 91.8 \\
Total & 73 & 100.0 \\
\hline
\end{tabular}


Table 5.

Cardiac Rehabilitation Enrollment Rate (All Isolated CABG patients)

\begin{tabular}{lcc}
\hline Variable & Frequency & Percent \\
\hline no & 28 & 38.4 \\
yes & 21 & 28.8 \\
Non-eligible & 24 & 32.9 \\
Total & 73 & 100.0 \\
\hline
\end{tabular}


Table 6.

Face-to-Face Promotion of Cardiac Rehabilitation Enrollment of Cardiac Rehabilitation Eligible Patients Crosstabulation

\begin{tabular}{lcccc}
\hline Variable & \multicolumn{2}{c}{ CR Enrollment } & Total \\
& & no & yes & \\
\hline \multirow{2}{*}{ Face-to-Face Promotion } & no & 2 & 2 & 4 \\
Total & yes & 26 & 19 & 45 \\
\hline
\end{tabular}


Table 7.

Chi-Square Test: Cardiac Rehabilitation Rates Among Cardiac Rehabilitation Eligible Clients

\begin{tabular}{lccc}
\hline & $\chi^{2}$ & $d f$ & $p$ \\
\hline Pearson Chi-Square & $.091^{\mathrm{a}}$ & 1 & .763 \\
Linear-by-Linear & .089 & 1 & .766 \\
Association & & & \\
\hline
\end{tabular}


Table 8.

ARNP Endorsement of Cardiac Rehabilitation Enrollment Impact

\begin{tabular}{|c|c|c|c|c|c|}
\hline \multirow[t]{2}{*}{ Variable } & & & \multicolumn{2}{|c|}{ ARNP Endorsement } & \multirow[t]{2}{*}{ Total } \\
\hline & & & no & yes & \\
\hline \multirow{6}{*}{ CR Enrollment } & & Count & 17 & 11 & 28 \\
\hline & no & $\%$ within $\mathrm{CR}$ & $60.7 \%$ & $39.3 \%$ & $100.0 \%$ \\
\hline & & Enrollment & & & \\
\hline & & Count & 8 & 13 & 21 \\
\hline & yes & $\%$ within $\mathrm{CR}$ & $38.1 \%$ & $61.9 \%$ & $100.0 \%$ \\
\hline & & Enrollment & & & \\
\hline \multirow{3}{*}{ Total } & & Count & 25 & 24 & 49 \\
\hline & & $\%$ within $\mathrm{CR}$ & $51.0 \%$ & $49.0 \%$ & $100.0 \%$ \\
\hline & & Enrollment & & & \\
\hline
\end{tabular}


Table 9.

Chi-Square Tests: ARNP Endorsement of Cardiac Rehabilitation Enrollment Impact

\begin{tabular}{lccc}
\hline & $\chi^{2}$ & $d f$ & $p$ \\
\hline Pearson Chi-Square & $2.457^{\mathrm{a}}$ & 1 & .117 \\
\hline
\end{tabular}


Table 10 .

GT8 RN Support of Cardiac Rehabilitation Enrollment Impact

\begin{tabular}{|c|c|c|c|c|c|}
\hline \multirow[t]{2}{*}{ Variable } & & & \multicolumn{2}{|c|}{ GT8 RN Support } & \multirow[t]{2}{*}{ Total } \\
\hline & & & no & yes & \\
\hline \multirow{4}{*}{ CR Enrollment } & \multirow{2}{*}{ no } & Count & 23 & 5 & 28 \\
\hline & & $\%$ within CR Enrollment & $82.1 \%$ & $17.9 \%$ & $100.0 \%$ \\
\hline & \multirow{2}{*}{ yes } & Count & 15 & 6 & 21 \\
\hline & & $\%$ within CR Enrollment & $71.4 \%$ & $28.6 \%$ & $100.0 \%$ \\
\hline \multirow{2}{*}{ Total } & & Count & 38 & 11 & 49 \\
\hline & & $\%$ within CR Enrollment & $77.6 \%$ & $22.4 \%$ & $100.0 \%$ \\
\hline
\end{tabular}


Table 11.

Chi-Square Test: GT8 RN Support of Cardiac Rehabilitation Enrollment Impact

\begin{tabular}{lccc}
\hline & $\chi^{2}$ & $d f$ & $p$ \\
\hline Pearson Chi-Square & $.791^{\mathrm{a}}$ & 1 & .374 \\
\hline
\end{tabular}


Table 12.

Discharge Nurse Endorsement of Cardiac Rehabilitation Enrollment Impact

\begin{tabular}{lllrrr}
\hline Variable & & \multicolumn{2}{c}{ Discharge RN } & Total \\
& & \multicolumn{2}{c}{ Endorsement } & \\
& & no & yes & \\
\hline \multirow{3}{*}{ CR Enrollment } & no & Count & 7 & 21 & 28 \\
& & \% within CR Enrollment & $25.0 \%$ & $75.0 \%$ & $100.0 \%$ \\
& \multirow{2}{*}{ yes } & Count & 4 & 17 & 21 \\
Total & & \% within CR Enrollment & $19.0 \%$ & $81.0 \%$ & $100.0 \%$ \\
& & Count & 11 & 38 & 49 \\
& & $\%$ within CR Enrollment & $22.4 \%$ & $77.6 \%$ & $100.0 \%$ \\
\hline
\end{tabular}


Table 13.

Chi-Square Tests: Discharge Nurse Endorsement of Cardiac Rehabilitation Enrollment Impact

\begin{tabular}{lccc}
\hline & $\chi^{2}$ & $d f$ & $p$ \\
\hline Pearson Chi-Square & $.244^{\mathrm{a}}$ & 1 & .621 \\
\hline
\end{tabular}


Table 14.

Chi-Square Test: Patient Barriers and Cardiac Rehabilitation Enrollment

$$
\chi^{2}
$$

$d f$ $p$ 
Figure 1.

\section{PRISMA Statement}
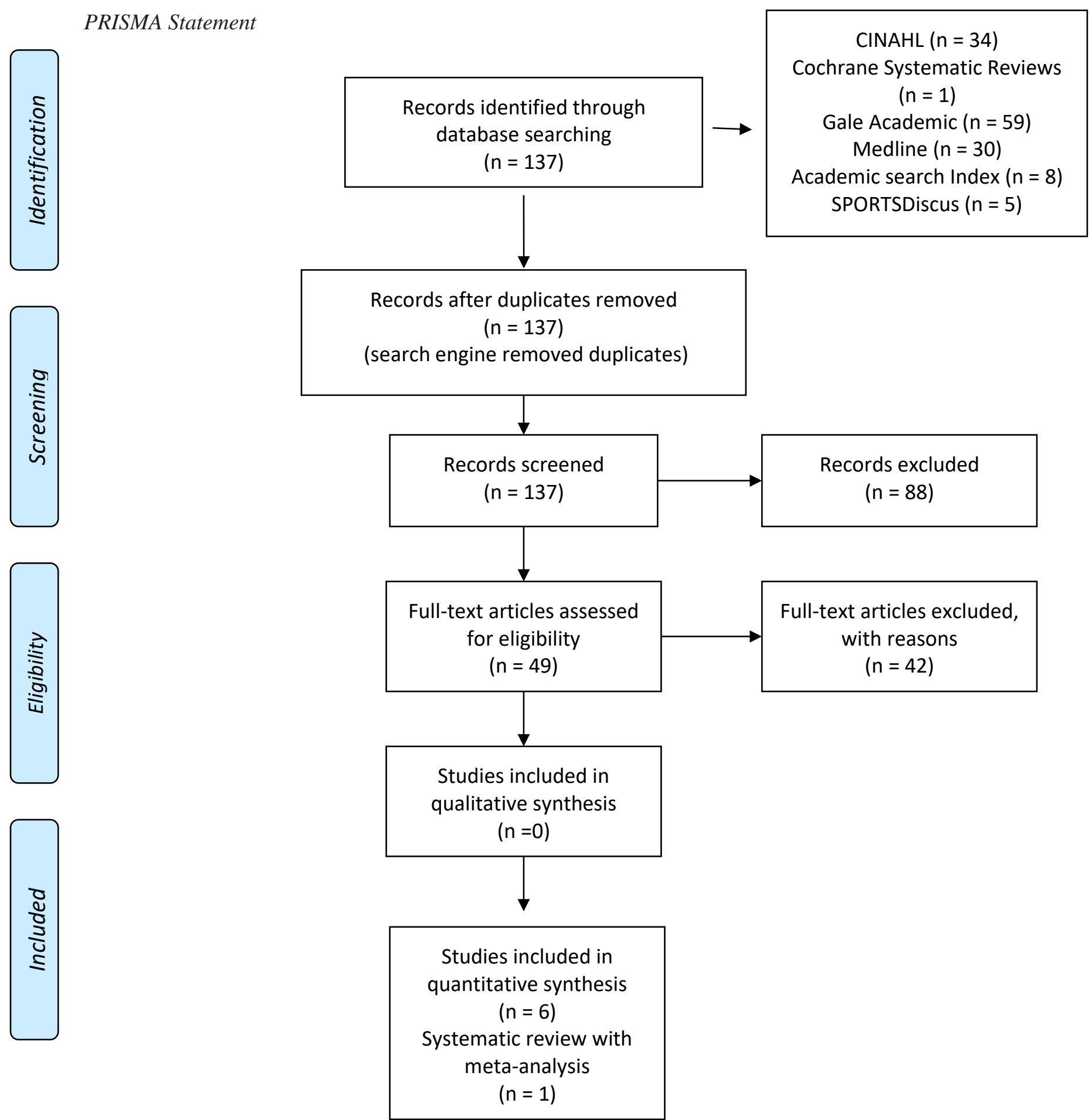

(Moher et al., 2009)

Note. Summary of full-text survey results from the evidence search 
Figure 2.

Recommendation to Answer the PICOT Question

Create a systematic process focusing on increasing enrollment rates into cardiac rehabilitation utilizing an interprofessional team

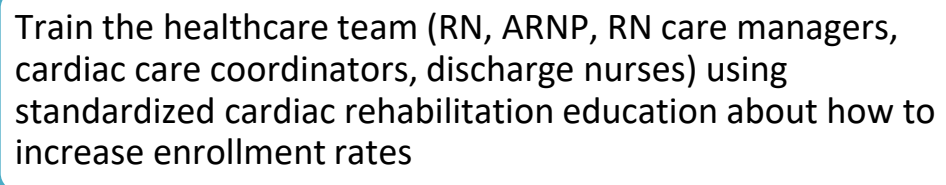

Cardiac rehabilitation (CR) champions (cardiac care coordinators) to provide face-to-face nursing promotion of cardiac rehabilitation supported by the staff $\mathrm{RN}$ and discharge nurses

Cardiology ARNPs to provide a strong endorsement of cardiac rehabilitation during patient rounds

RN care managers address patient's barriers to enrolling into cardiac rehabilitation and solve if possible

Note. This is a visual depiction of the recommendations from synthesizing the primary articles to increase enrollment rates into cardiac rehabilitation. 
Figure 3.

Healthcare Organization SWOT Analysis

\section{Strength}

- High quality outcomes

- Leadership focus on EBP changes

- Cardiac rehab in house

- Required healthcare professional

- Vast resources

- High levels of staff competency

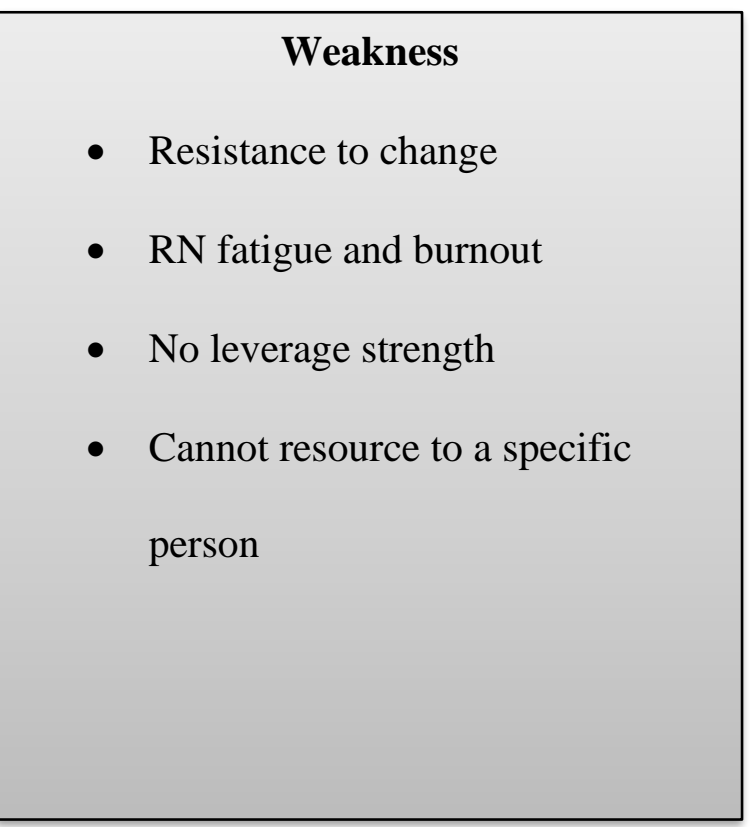

Threats

- New initiative

- Current workloads

- High RN turnover

- CMS policy changes

- Change in payor 
Figure 4.

Face-to-Face Nursing Cardiac Rehabilitation Promotion Systemic Process

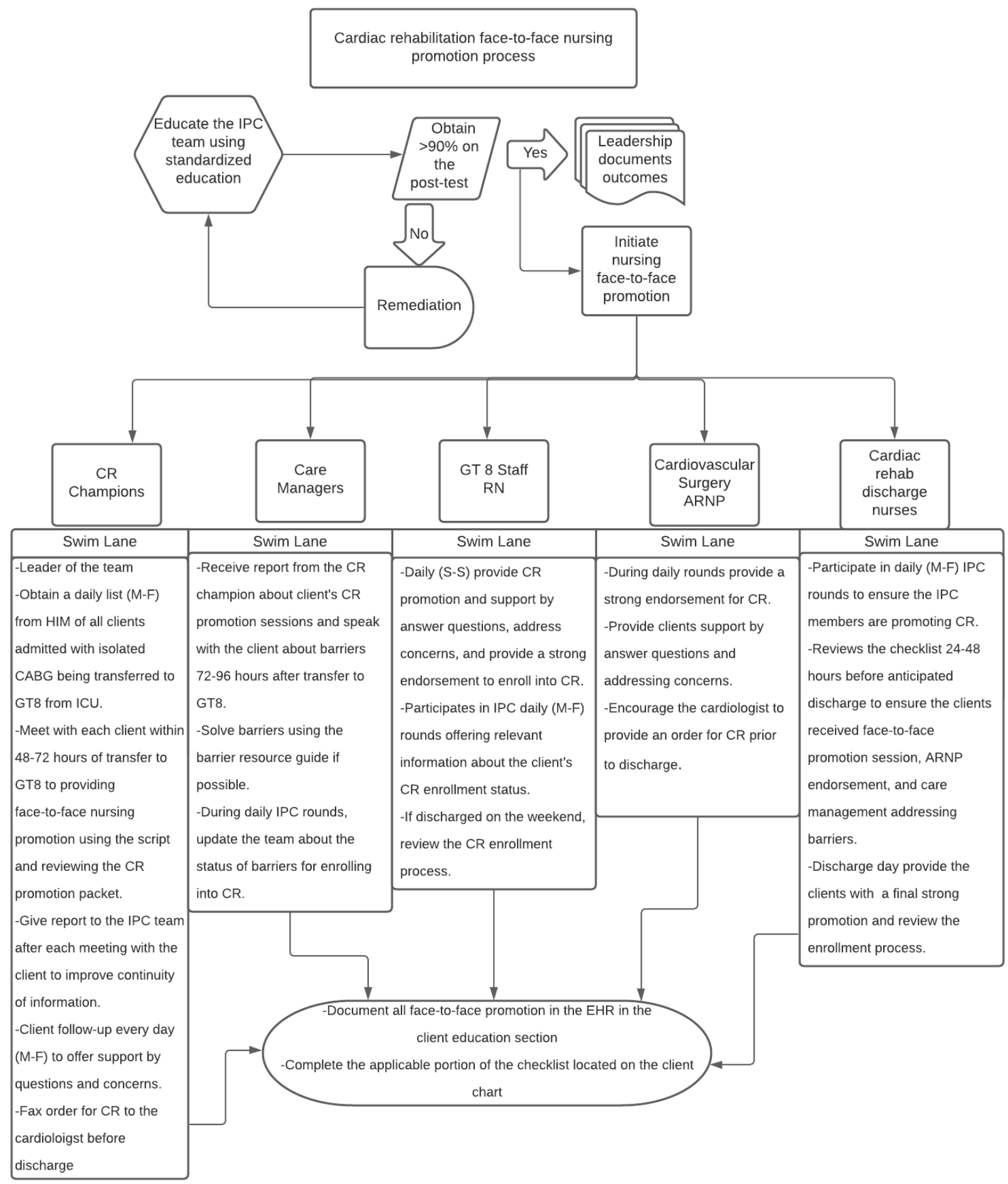


Figure 5.

\section{G*Power Sample Size Calculation Required for Chi-Square Test}

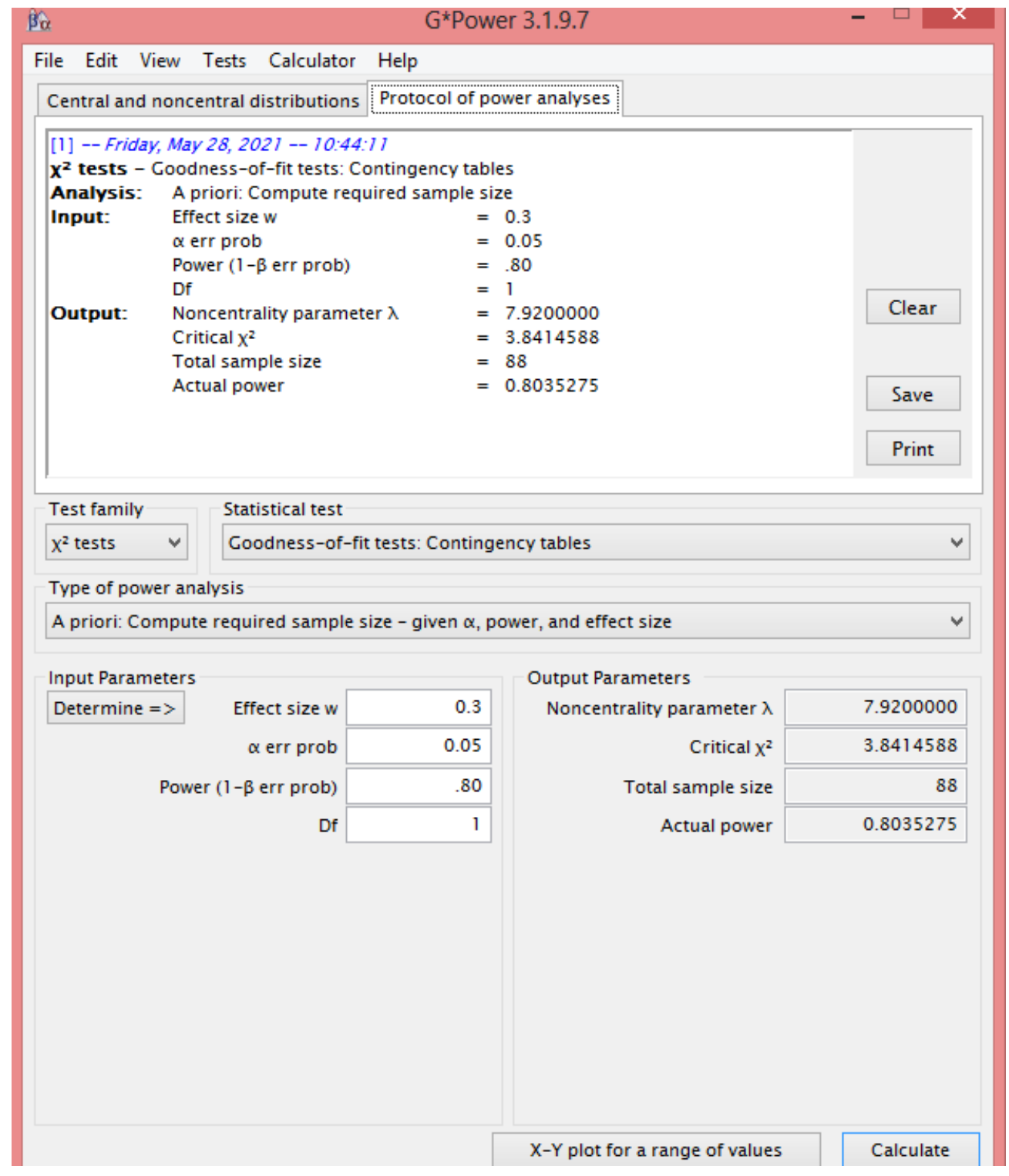


Appendix A

Summary of Primary Research Evidence

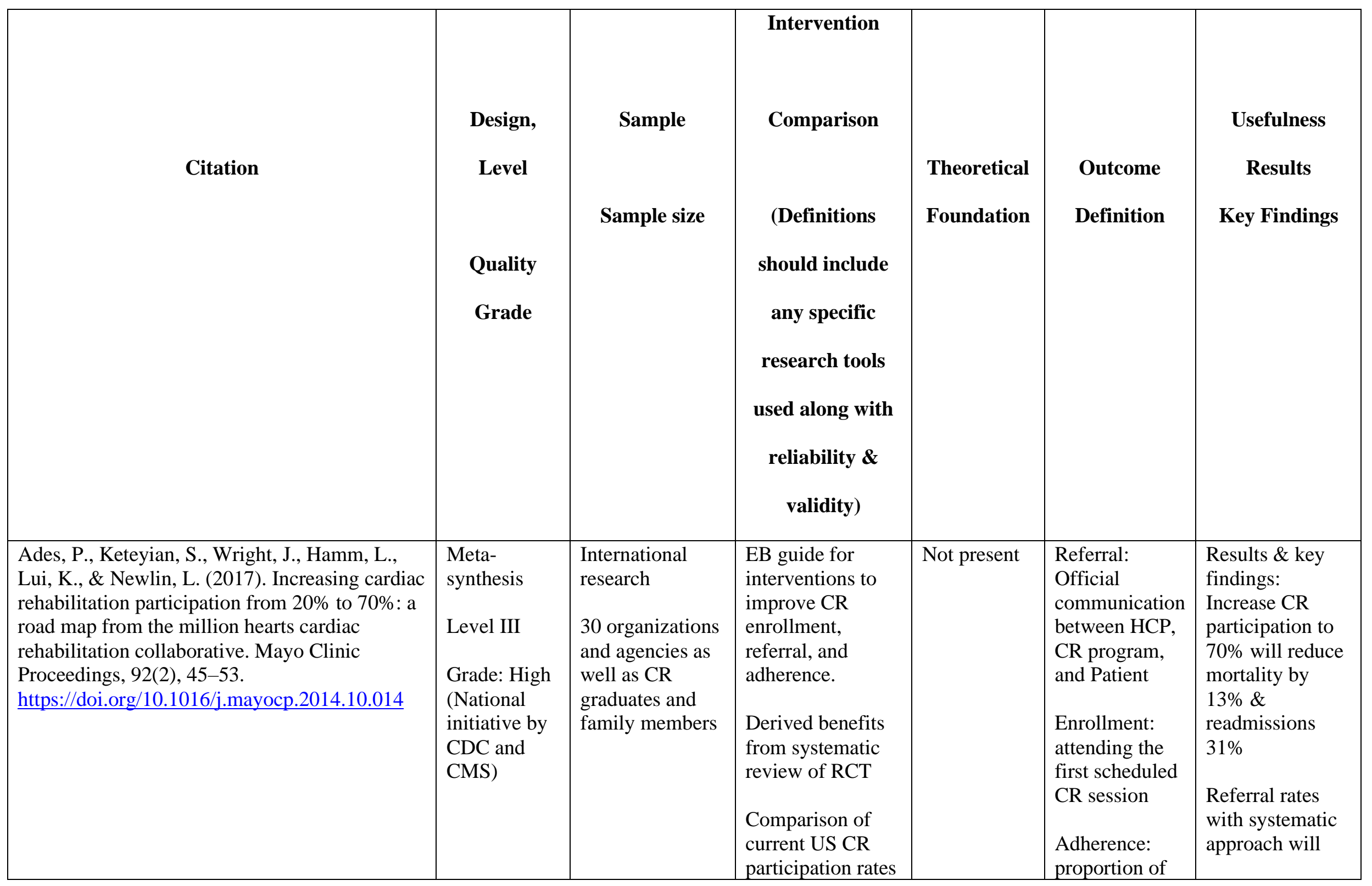




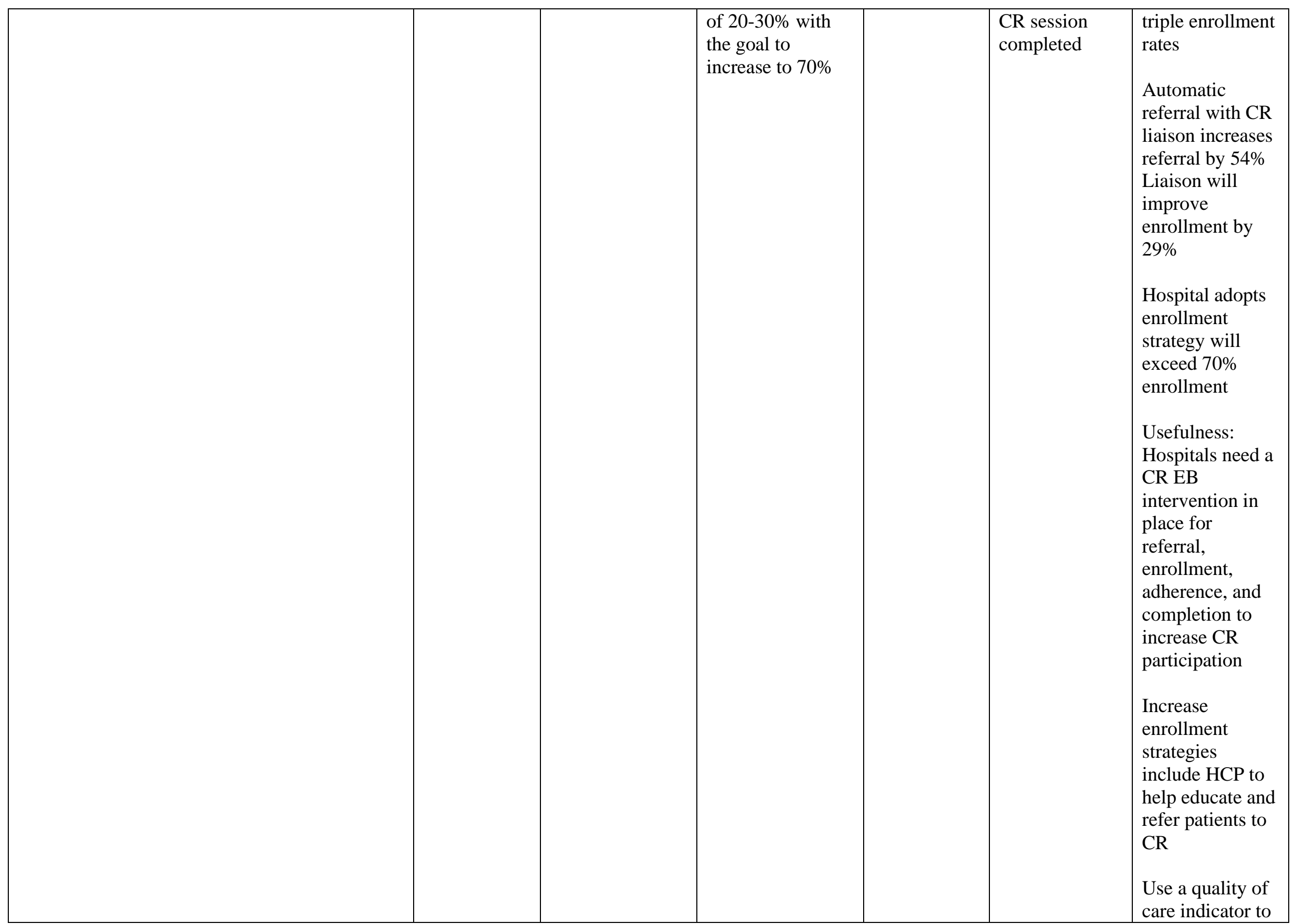




\begin{tabular}{|c|c|c|c|c|c|c|}
\hline & & & & & & $\begin{array}{l}\text { improve } \\
\text { enrollment. }\end{array}$ \\
\hline $\begin{array}{l}\text { Ali-Faisal, S. F., Benz Scott, L., Johnston, L., \& } \\
\text { Grace, S. L. (2016). Cardiac rehabilitation } \\
\text { referral and enrolment across an academic } \\
\text { health sciences centre with ereferral and peer } \\
\text { navigation: A randomised controlled pilot trial. } \\
\text { BMJ Open, 6(3), e010214. } \\
\text { https://doi.org/10.1136/bmjopen-2015-010214 }\end{array}$ & $\begin{array}{l}2 \text { parallel- } \\
\text { arm, } \\
\text { randomized, } \\
\text { single- } \\
\text { blinded trial } \\
\text { with } \\
\text { allocation } \\
\text { concealment } \\
\text { Level I } \\
\text { Quality: } \\
\text { High }\end{array}$ & $\begin{array}{l}3 \text { cardiac units in } \\
\text { a tertiary center } \\
\text { in Canada } \\
\text { Cardiac inpatient } \\
\text { eligible for CR } \\
(\mathrm{n}=92)\end{array}$ & $\begin{array}{l}\text { Intervention along } \\
\text { with e-referral: } \\
\text {-PN visiting } \\
\text { Patient at bedside } \\
\text { to educate and } \\
\text { endorse CR } \\
\text {-Mail card to } \\
\text { Patient's home } \\
\text { about CR } \\
\text { enrollment } \\
\text {-Call participants } \\
2 \text { weeks after } \\
\text { discharge to } \\
\text { encourage CR } \\
\text { Comparison to } \\
\text { usual treatment } \\
\text { (no PN } \\
\text { engagement, only } \\
\text { e-referral) } \\
\text { PN trained to } \\
\text { provide CR } \\
\text { focused education } \\
\text { and support. } \\
\text { All PN contact } \\
\text { was documented } \\
\text { for establish } \\
\text { consistency and } \\
\text { fidelity. } \\
\text { Dichotomous data } \\
\text { collection if } \\
\text { enrolled into CR. } \\
\text { T-test or Fisher's } \\
\text { exact test to } \\
\text { compare clinical }\end{array}$ & Not present & $\begin{array}{l}\text { eReferral: } \\
\text { automatic } \\
\text { populated } \\
\text { referral for the } \\
\text { doctor to select } \\
\text { Referral: } \\
\text { CR program } \\
\text { receipt of } \\
\text { documentation } \\
\text { from doctor to } \\
\text { refer the } \\
\text { Patient }\end{array}$ & $\begin{array}{l}\text { Results \& key } \\
\text { findings: } \\
\text { Cardiac unit CR } \\
\text { referral } 78 \% \\
\text { compared to } \\
\text { general } \\
\text { cardiology unit } \\
61 \%, \& \\
\text { interventional } \\
\text { unit } 33 \% \\
\text { Location of CR } \\
\text { center greatest } \\
\text { impact to enroll } \\
\text { (77\% close vs } \\
23 \% \text { far, p=0.04) } \\
\text { PN arm group } \\
11 \% \text { increase in } \\
\text { enrollment but } \\
\text { not significant } \\
\text { (p=0.24) } \\
\text { eRefferal } \\
\text { decreased } \\
\text { common bias. } \\
\text { Usefulness: } \\
\text { The type of unit } \\
\text { has an impact on } \\
\text { CR enrollment } \\
\text { and referral } \\
\text { Need to provide } \\
\text { education to } \\
\text { HCP about CR } \\
\text { benefits, and } \\
\text { clinical practice } \\
\text { guidelines }\end{array}$ \\
\hline
\end{tabular}




\begin{tabular}{|c|c|c|c|c|c|c|}
\hline & & & $\begin{array}{l}\text { characteristics } \\
\text { obtained 12-week } \\
\text { post d/c chart } \\
\text { extraction }\end{array}$ & & & \\
\hline $\begin{array}{l}\text { Cossette, S., Frasure-Smith, N., Dupuis, J., } \\
\text { Juneau, M., \& Guertin, M.-C. (2012). } \\
\text { Randomized controlled trial of tailored nursing } \\
\text { interventions to improve cardiac rehabilitation } \\
\text { enrollment. Nursing Research, 61(2), 111-120. } \\
\text { https://doi.org/10.1097/nnr.0b013e318240dc6b }\end{array}$ & $\begin{array}{l}\text { Experimental } \\
\text { RCT- } \\
\text { randomized } \\
\text { \& blinded } \\
\text { Level I } \\
\text { Grade: High }\end{array}$ & $\begin{array}{l}\text { Inpatients } \\
\text { suspected of } \\
\text { ACS in a cardiac } \\
\text { hospital }(n=242) \\
\text { Power of } .80 \& \\
\text { two-sided alpha } \\
\text { of } .05\end{array}$ & $\begin{array}{l}\text { Intervention: } \\
\text { One face-to-face } \\
\text { nurse-patient visit } \\
\text { before d/c with } \\
\text { CR specific } \\
\text { information with } \\
2 \text { more contacts } \\
\text { over } 10 \text { days after } \\
\text { d/c (either phone } \\
\text { or in person) } \\
\text { Comparison: } \\
\text { usual care nurses } \\
\text { provide during } \\
\text { hospital stay, } 1 \\
\text { phone call by } \\
\text { research assistant, } \\
\text { and } 2 \text { nd call by } \\
\text { staff blinded by } \\
\text { assignment to } \\
\text { encourage } \\
\text { enrollment in CR } \\
\text { Chi-square test for } \\
\text { primary outcomes } \\
\text { Logistic } \\
\text { regression to } \\
\text { assess models } \\
\text { adjusting baseline } \\
\text { variables } \\
\text { Logistic } \\
\text { regression model } \\
\text { for } 2 \text { ndary } \\
\text { outcomes }\end{array}$ & $\begin{array}{l}\text { Leventhal's } \\
\text { Self- } \\
\text { Regulation } \\
\text { Theory }\end{array}$ & $\begin{array}{l}\text { Enrollment: } \\
\text { attend at least } \\
\text { one CR session } \\
\text { within } 6 \text { weeks } \\
\text { of } d / c\end{array}$ & $\begin{array}{l}\text { Results \& key } \\
\text { findings: Results } \\
\text { in line with } \\
\text { numerous RCT } \\
\text { evaluating CR } \\
\text { enrollment after } \\
\text { liaison type } \\
\text { intervention } \\
\text { Meeting times } \\
\text { for } 3 \text { encounters } \\
\text { lasted 30-240 } \\
\text { minutes } \\
\text { Intervention } \\
\text { group had higher } \\
\text { enrollment rates } \\
\text { (45\%) compared } \\
\text { to control group } \\
\text { (24\%) (p<.001) } \\
\text { unadjusted odds } \\
\text { ratio associated } \\
\text { with intervention } \\
2.56,95 \% \text { CI } \\
\text { Consider other } \\
\text { variable with } \\
\text { enrollment: } \\
\text { accessibility, } \\
\text { distance, } \\
\text { employment, } \\
\text { education, prior } \\
\text { CVD (all p } \\
<0.01 \text { ) } \\
\text { Time of } \\
\text { enrollment did }\end{array}$ \\
\hline
\end{tabular}




\begin{tabular}{|c|c|c|c|c|c|c|}
\hline & & & $\begin{array}{l}\text { Enrollment data } \\
\text { was collected in } \\
\text { computerized } \\
\text { database also } \\
\text { independent data } \\
\text { entry } \\
\text { Illness perception: } \\
\text { 38-item IPQ-R } \\
\text { (alpha coefficient } \\
\text {.79-.89) Test } \\
\text { reliability good } \\
\text { stability \& } \\
\text { correlations .63- } \\
\text {.88. } \\
\text { Family support } \\
\text { perception: } 14- \\
\text { item Family Care } \\
\text { Climate } \\
\text { Questionnaire } \\
\text { Patient version } \\
\text { (Cronbach's alpha } \\
\text { of .89) } \\
\text { Medication } \\
\text { adherence: 4-item } \\
\text { Self-Reported } \\
\text { Medication- } \\
\text { Taking Survey } \\
\text { (lack variability) }\end{array}$ & & & $\begin{array}{l}\text { not differ } \\
\text { between groups } \\
\text { Variable illness } \\
\text { perception only } \\
\text { 2ndary outcomes } \\
\text { difference } \\
\text { between groups } \\
\text { Usefulness: } \\
\text { Nurses are } \\
\text { frontline of } \\
\text { providing care- } \\
\text { scientific } \\
\text { knowledge, } \\
\text { combined with } \\
\text { clinical expertise } \\
\text { to improve } \\
\text { patient outcomes } \\
\text { Face-to-face CR } \\
\text { nurse/patient } \\
\text { visit increase } \\
\text { enrollment rates }\end{array}$ \\
\hline $\begin{array}{l}\text { Grossman, J. (2015). Cardiac rehabilitation } \\
\text { enrollment and the impact of systematic nursing } \\
\text { interventions for postmyocardial infarction and } \\
\text { stent patients. Clinical Nursing Research, 25(4), } \\
\text { 378-390. } \\
\text { https://doi.org/10.1177/1054773815620777 }\end{array}$ & $\begin{array}{l}\text { RCT } \\
\text { Level I } \\
\text { Quality: } \\
\text { High }\end{array}$ & $\begin{array}{l}\text { Urban acute care } \\
\text { hospital patients } \\
\text { admitted with } \\
\text { postMI with } \\
\text { stent placement } \\
(\mathrm{n}=104)\end{array}$ & $\begin{array}{l}\text { Determine most } \\
\text { effective } \\
\text { intervention for } \\
\text { enhancing CR } \\
\text { enrollment } \\
\text { Intervention: }\end{array}$ & Not present & $\begin{array}{l}\text { Enrollment: } \\
\text { full } \\
\text { participation in } \\
\text { the first of } 36 \\
\text { CR exercise } \\
\text { sessions after } \\
\text { having } \\
\text { completed all }\end{array}$ & $\begin{array}{l}\text { Results \& key } \\
\text { findings: } \\
\text { Patients who } \\
\text { received face-to- } \\
\text { face nursing } \\
\text { intervention } \\
\text { were more likely } \\
\text { to enroll }\end{array}$ \\
\hline
\end{tabular}




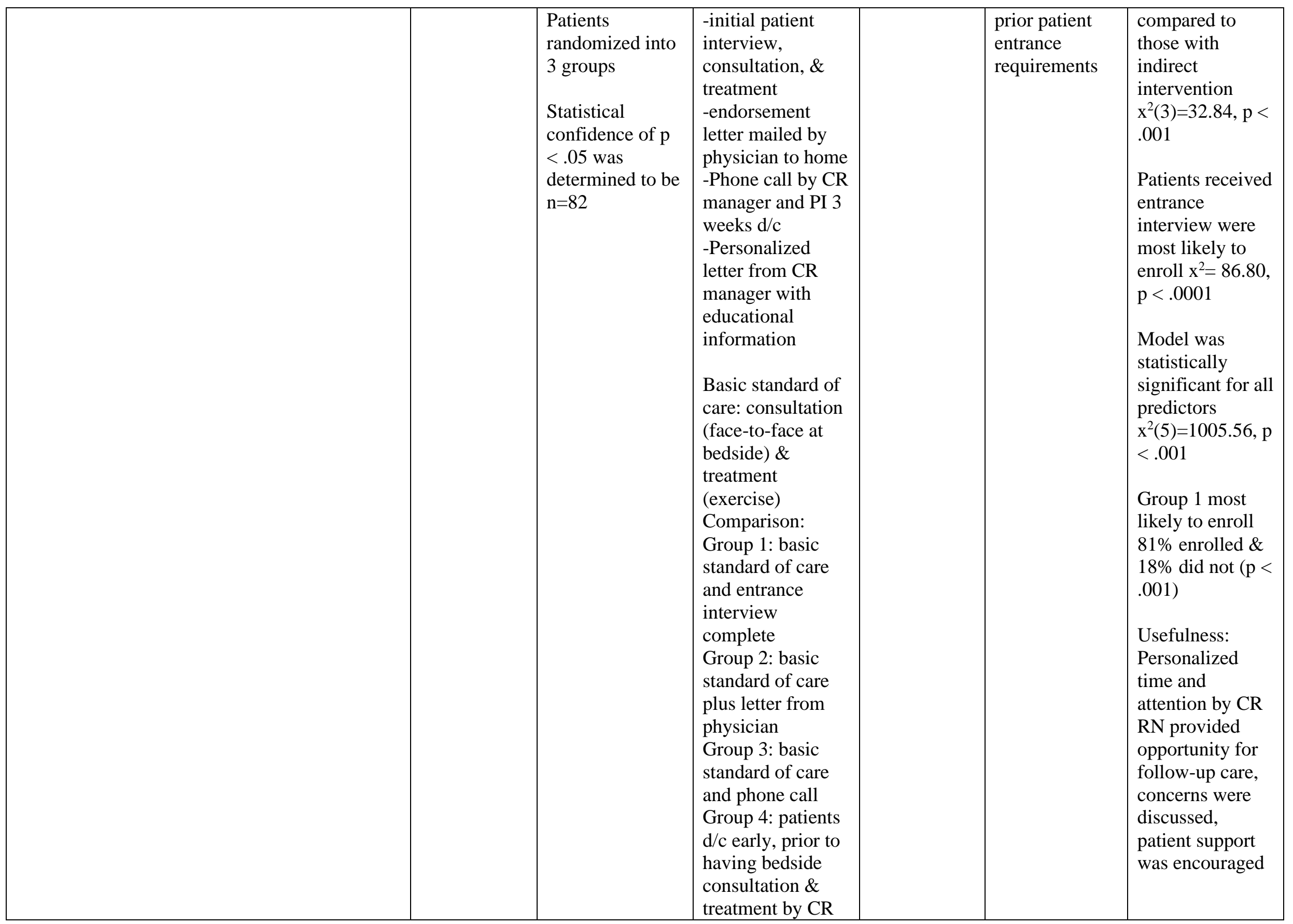




\begin{tabular}{|c|c|c|c|c|c|c|}
\hline & & & $\begin{array}{l}\text { RN, received CR } \\
\text { manager letter at } \\
\text { home } \\
\text { SPSS for } \\
\text { statistical } \\
\text { analysis, } \\
\text { descriptive stats } \\
\text { and frequency } \\
\text { distribution for } \\
\text { population } \\
\text { characteristics } \\
\text { 2-way chi-square } \\
\text { to determine } \\
\text { relationship } \\
\text { between } \\
\text { intervention \& CR } \\
\text { enrollment } \\
\text { (Confidence level } \\
\text { 95\% \& } \\
\text { confidence } \\
\text { interval of 5) } \\
\text { Direct logistical } \\
\text { regression to } \\
\text { assess effect on } \\
\text { factors regarding } \\
\text { patient enrollment }\end{array}$ & & & $\begin{array}{l}\text { CR RN creating } \\
\text { seamless } \\
\text { continuum for } \\
\text { patients to OCR } \\
\text { results in } \\
\text { enhancing CR } \\
\text { enrollment } \\
\text { Patients who } \\
\text { received face-to- } \\
\text { face nursing } \\
\text { intervention } \\
\text { were more likely } \\
\text { to enroll } \\
\text { compared to } \\
\text { those with } \\
\text { indirect } \\
\text { intervention }\end{array}$ \\
\hline $\begin{array}{l}\text { Santiago de Araújo Pio, C., Gagliardi, A., } \\
\text { Suskin, N., Ahmad, F., \& Grace, S. L. (2020b). } \\
\text { Implementing recommendations for inpatient } \\
\text { healthcare provider encouragement of cardiac } \\
\text { rehabilitation participation: Development and } \\
\text { evaluation of an online course. BMC Health } \\
\text { Services Research, 20(1). } \\
\text { https://doi.org/10.1186/s12913-020-05619-2 }\end{array}$ & $\begin{array}{l}\text { Multimethod } \\
\text { with } \\
\text { stepwise } \\
\text { approach } \\
\text { Level II } \\
\text { Quality: } \\
\text { High }\end{array}$ & $\begin{array}{l}\text { Sample: } \\
\text { HCP from } \\
\text { academic } \\
\text { hospitals in } \\
\text { Toronto } \\
\text { Needs } \\
\text { assessment: } n=7 \\
\text { Tool pilot test: } \\
n=5 \\
\text { Formative tool } \\
\text { evaluation: } n=24\end{array}$ & $\begin{array}{l}\text { Describe the } \\
\text { development and } \\
\text { evaluation of a } \\
\text { guidance CR } \\
\text { implementation } \\
\text { tools } \\
\text { Interventions: } \\
\text { Needs } \\
\text { assessment: }\end{array}$ & $\begin{array}{l}\text { Kirkpatrick's } \\
\text { Model of } \\
\text { Training }\end{array}$ & $\begin{array}{l}\text { CR educational } \\
\text { needs: } \\
\text {-what is CR } \\
\text {-benefits of CR } \\
\text {-Importance } \\
\text { with } \\
\text { endorsement } \\
\text {-questions by } \\
\text { patients } \\
\text {-Barrier } \\
\text { discussion }\end{array}$ & $\begin{array}{l}\text { Results: } \\
\text { Needs } \\
\text { assessment } \\
\text { demonstrated a } \\
\text { need for HCP } \\
\text { CR } \\
\text { education.62\% } \\
\text { HCP initiated } \\
\text { CR conversation } \\
\text { with patient } \\
\text { lasting on }\end{array}$ \\
\hline
\end{tabular}




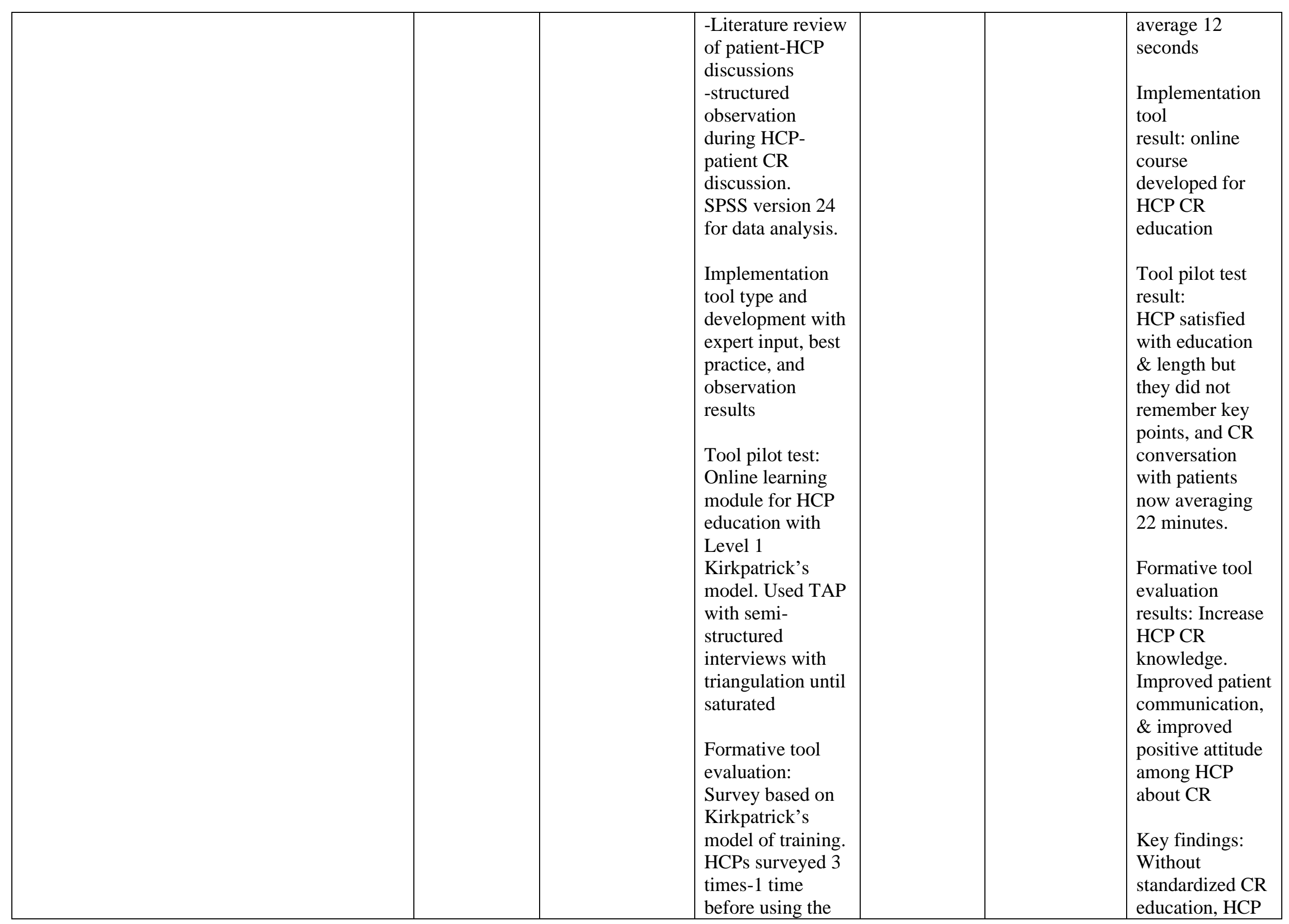




\begin{tabular}{|c|c|c|c|c|c|c|}
\hline & & & $\begin{array}{l}\text { developed tool, } \\
\text { after using the } \\
\text { tool, and one } \\
\text { month later. } \\
\text { SPSS version } 24 \\
\text { to compare pre } \\
\text { and post-test with } \\
\text { t-test and Chi- } \\
\text { square. }\end{array}$ & & & $\begin{array}{l}\text { provided } \\
\text { information that } \\
\text { was grossly } \\
\text { insufficient and } \\
\text { inaccurate. } \\
\text { Usefulness: } \\
\text { Use standardized } \\
\text { HCP CR } \\
\text { educational } \\
\text { material } \\
\text { endorsed by } 23 \\
\text { medical societies } \\
\text { and } 39 \text { ICCPR } \\
\text { societies } \\
\text { Majority of HCP } \\
\text { require } \\
\text { additional } \\
\text { education about } \\
\text { CR. } \\
\text { HCPs should use } \\
\text { educational tools } \\
\text { provided and } \\
\text { endorsed by CR } \\
\text { experts }\end{array}$ \\
\hline $\begin{array}{l}\text { Scott, L., Gravely, S., Sexton, T. R., Brzostek, } \\
\text { S., \& Brown, D. L. (2013). Examining the effect } \\
\text { of a patient navigation intervention on } \\
\text { outpatient cardiac rehabilitation awareness and } \\
\text { enrollment. Journal of Cardiopulmonary } \\
\text { Rehabilitation and Prevention, 33(5), 281-291. } \\
\text { https://doi.org/10.1097/hcr.0b013e3182972dd6 }\end{array}$ & $\begin{array}{l}\text { Experimental } \\
\text { RCT } \\
\text { Level: } 1 \\
\text { Quality: } \\
\text { High }\end{array}$ & $\begin{array}{l}\text { CR eligible } \\
\text { patients }>21 \text { yo } \\
\text { on a cardiology } \\
\text { or thoracic } \\
\text { medical unit } \\
(\mathrm{n}=181) \\
\\
\text { Measures: } \\
\text { Data extracted } \\
\text { from medical } \\
\text { records and self- } \\
\text { reported from }\end{array}$ & $\begin{array}{l}2 \text { PN trained to } \\
\text { provide basic CR } \\
\text { education, } \\
\text { support, and } \\
\text { encourage } \\
\text { enrollment. } \\
-1 \text { visit at the } \\
\text { Patient's bedside } \\
-1 \text { phone call } 1 \\
\text { week after d/c } \\
-1 \text { CR } \\
\text { endorsement letter } \\
\text { mailed }\end{array}$ & Not present & $\begin{array}{l}\text { Enrollment: } \\
\text { attend at least } \\
1 \mathrm{CR} \text { session }\end{array}$ & $\begin{array}{l}\text { Results: } \\
\text { PN arm } 6 \text { times } \\
\text { more likely to } \\
\text { have more } \\
\text { awareness of } \\
\text { OCR }(\mathrm{OR}=5.99 \text {, } \\
\mathrm{p}=0.001) \\
\text { Patients who } \\
\text { report increased } \\
\text { awareness of } \\
\text { OCR were } 9\end{array}$ \\
\hline
\end{tabular}




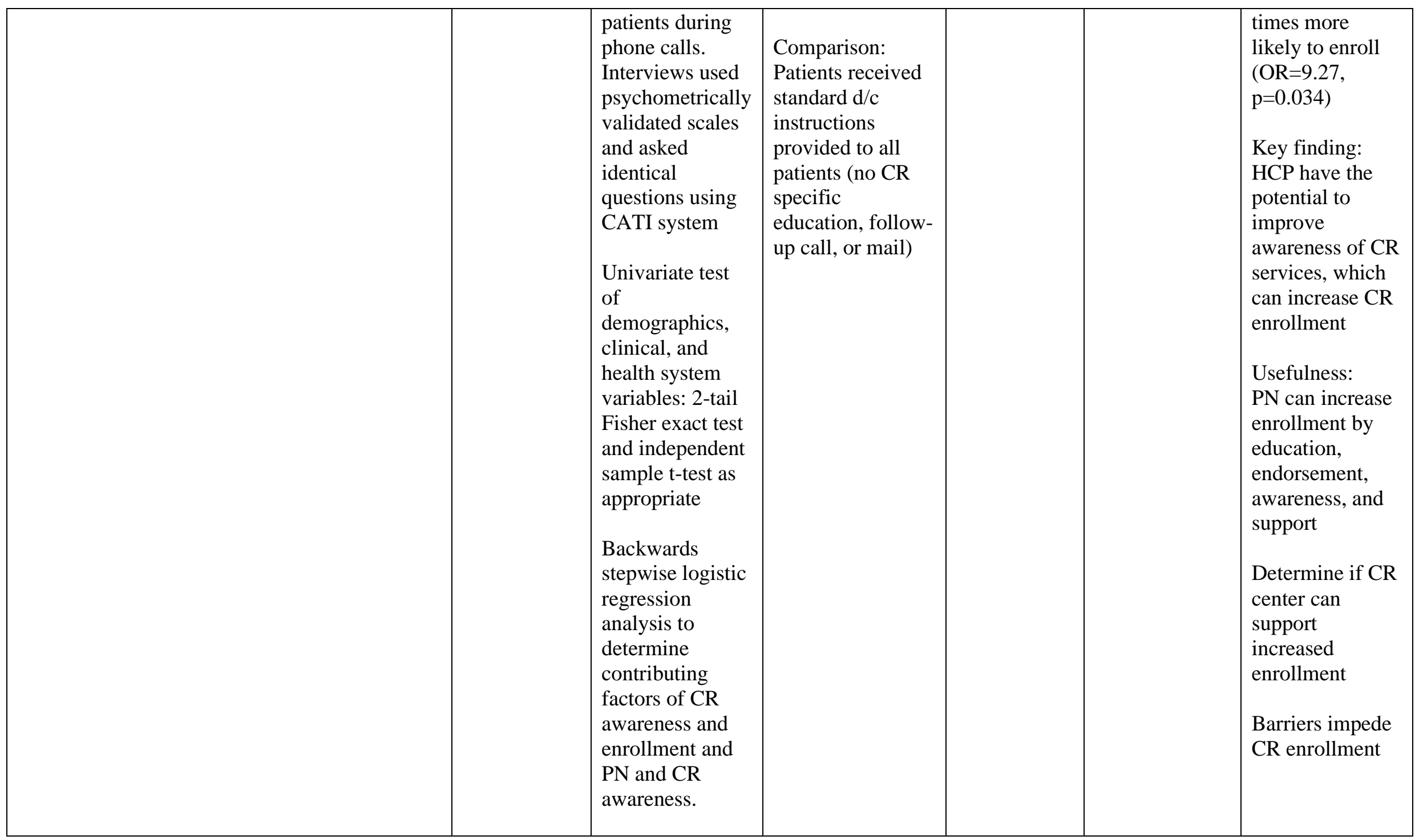

Legend: ACS: Acute coronary syndrome, AHRQ: Agency for Healthcare Research and Quality, CACPR: Canadian Association of Cardiovascular Prevention and Rehabilitation, CATI: Computer-assisted telephone interviewing, CDC: Centers for Disease Control and Prevention, CI: Confidence interval , CMS: Center for Medicare and Medicaid, CR/OCR: cardiac rehabilitation (United States)/Outpatient cardiac rehabilitation , D/C:

Discharge, EB: Evidence-based, HCP: Healthcare provider (i.e. Doctor, extender (ARNP, PA), nurse, allied health), ICCPR: International Council of Cardiovascular Prevention and Rehabilitation, IPQ-R: Illness Perception Questionnaire , MI: Myocardial infarction , MD: Medical doctor (physician), PN: Patient navigator, RATS: Relevance of study questions, Appropriateness of method, Transparency of procedures, Soundness of 
interpretative approach , RCT: Randomized controlled trial, RN: Registered nurse, PT: Physical therapy, SMD: standard mean difference, TAP: think-aloud protocol, WHO: World Health Organization 
Appendix B

Summary of Systematic Reviews (SR)

\begin{tabular}{|c|c|c|c|c|c|c|c|}
\hline Citation & $\begin{array}{l}\text { Quality } \\
\text { Grade }\end{array}$ & Question & Search Strategy & $\begin{array}{l}\text { Inclusion/ } \\
\text { Exclusion Criteria }\end{array}$ & $\begin{array}{l}\text { Data Extraction and } \\
\text { Analysis }\end{array}$ & Key Findings & $\begin{array}{l}\text { Usefulness/Recom } \\
\text { mendation/ } \\
\text { Implications }\end{array}$ \\
\hline \begin{tabular}{|l|} 
Pio, C., \\
Chaves, \\
G., \\
Davies, \\
P., \\
Taylor, \\
R., \& \\
Grace, S. \\
(2019a). \\
Intervent \\
ions to \\
promote \\
patient \\
utilizatio \\
n of \\
cardiac \\
rehabilita \\
tion: \\
Cochrane \\
systemati \\
c review \\
and \\
meta- \\
analysis. \\
Journal \\
of \\
Clinical \\
Medicine \\
, $8(2)$, \\
189. \\
\end{tabular} & \begin{tabular}{|l} 
Level \\
II \\
High \\
Meta- \\
analysi \\
s \\
\\
\end{tabular} & $\begin{array}{l}\text { Evaluating } \\
\text { interventions that } \\
\text { promote utilization of } \\
\text { CR and identify } \\
\text { effective interventions } \\
\text { to increase CR } \\
\text { enrollment }\end{array}$ & \begin{tabular}{|l|} 
Designed in \\
accordance with \\
Cochrane Heart \\
Group methods \\
Cochrane and \\
MEDLINE with \\
various other \\
databases with \\
hand-search \\
systematic reviews \\
and meta-analysis \\
resulting in 26 RCT \\
and n=5299 \\
Clarified missing, \\
unreported, and \\
ongoing trials with \\
authors and experts. \\
\end{tabular} & $\begin{array}{l}\text { Inclusion: } \\
\text { Randomized, quasi- } \\
\text { randomized controlled } \\
\text { trials (individualized or } \\
\text { cluster level) with parallel } \\
\text { groups or cross-over } \\
\text { designs } \\
\text { Study participants: } \\
\text { Adults who are eligible } \\
\text { for CR } \\
\text { Study interventions: } \\
\text { Increasing CR adherence } \\
\text { or completion } \\
\text { Any intervention with } \\
\text { aim to increase CR } \\
\text { utilization } \\
\text { Independently verified by } \\
2 \text { authors if met inclusion } \\
\text { criteria } \\
\text { Exclusion: } \\
\text { Wrong interventions } \\
\text { Outcome not of interest } \\
\text { Not comprehensive } \\
\text { Wrong study design }\end{array}$ & $\begin{array}{l}\text { Data extraction } \\
\text { based on } 2 \text { templets } \\
\text { and protocols. } \\
\text { Authors } \\
\text { independently } \\
\text { extracted data } \\
\text { Dichotomous } \\
\text { outcomes expressed } \\
\text { as risk ratio with } \\
\text { 95\% CI } \\
\text { Meta-analysis- } \\
\text { RevMan 5.3 and } \\
\text { results pooled by } \\
\text { random-effects } \\
\text { meta-analysis with } \\
\text { DerSimonian-Laird } \\
\text { method } \\
\text { Quantitative data } \\
\text { by Chi }{ }^{2} \& I^{2} \\
\text { statistic } \\
\text { Univariate meta- } \\
\text { regression in } \\
\text { STATA version } \\
15.1 \text { (when >10 }\end{array}$ & $\begin{array}{l}\text { Intervention deliverer } \\
\text { (nurse or allied health } \\
\text { provider, p=0.02) and } \\
\text { delivery format (face- } \\
\text { to-face, } \mathrm{p}=0.01 \text { ) } \\
\text { increased CR } \\
\text { enrollment } \\
\text { Remotely offered CR } \\
\text { improved adherence } \\
\text { (SMD=0.56, 95\% CI= } \\
\text { 0.36-0.76) } \\
\text { Interventions to } \\
\text { increase CR } \\
\text { completion were } \\
\text { effective (RR=1.13, } \\
95 \% \text { CI=1.02-1.25) } \\
\text { Intervention } \\
\text { effectiveness } \\
\text { identified under- } \\
\text { represented groups } \\
\text { (minorities, low } \\
\text { income, } \\
\text { comorbidities) } \\
\end{array}$ & $\begin{array}{l}\text { Nurse's deliver } \\
\text { standardized face- } \\
\text { to-face promotion } \\
\text { of CR at the } \\
\text { bedside } \\
\text { Online courses } \\
\text { available to } \\
\text { educate healthcare } \\
\text { providers how to } \\
\text { discuss CR with } \\
\text { patients at bedside }\end{array}$ \\
\hline
\end{tabular}




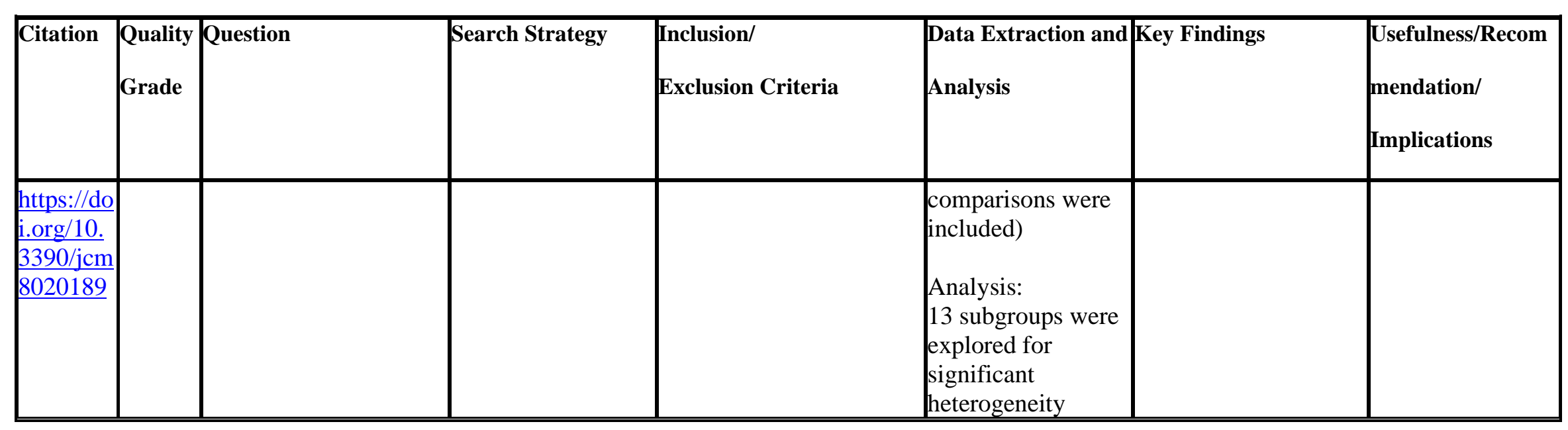


Appendix C

\section{Project Schedule}

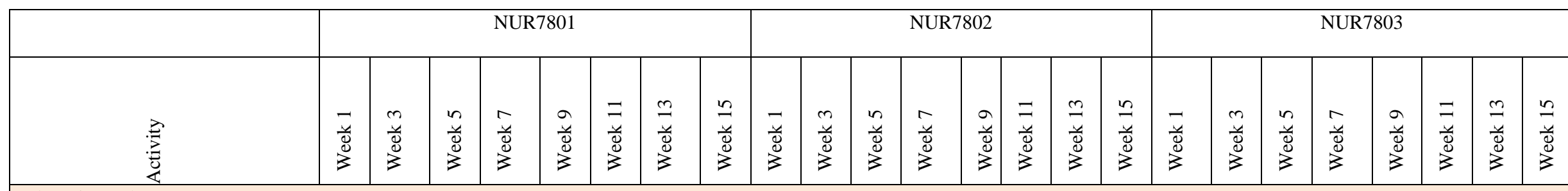

Planning Phase

Meet with research mentors

Meet with preceptor

Complete literature review

to support PICOT

Complete literature review

for current knowledge

Review and determine

which internally approved

standards and process and

educational material to

utilize

Finalize a specific aim with

clear outcomes

Finalize key stakeholders

with the preceptor and

review current data

Internal Data Collection

Obtain data about CR

enrollment numbers

Obtain data about CVD

statistics reported to the STS

database

Obtain data about CMS

CVD premier benchmark

outcomes
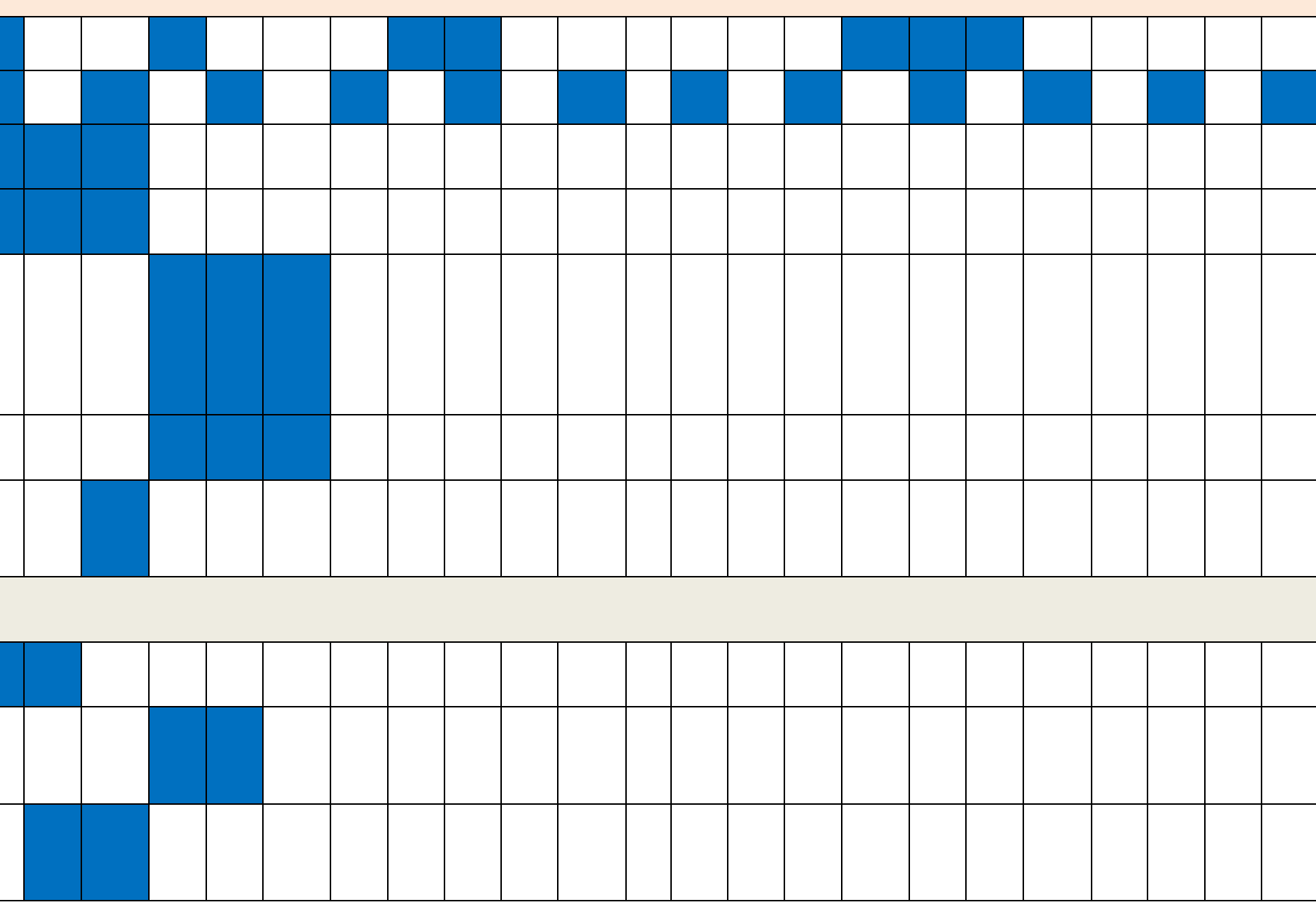


\begin{tabular}{|c|c|c|c|c|c|c|c|c|c|c|c|c|c|c|c|c|c|c|c|c|c|c|c|c|}
\hline & \multicolumn{8}{|c|}{ NUR7801 } & \multicolumn{8}{|c|}{ NUR7802 } & \multicolumn{8}{|c|}{ NUR7803 } \\
\hline$\stackrel{\substack{D \\
0}}{\stackrel{0}{4}}$ & $\frac{\bar{y}}{8}$ & $\frac{n}{2}$ & $\begin{array}{l}n \\
\frac{4}{8} \\
z\end{array}$ & $\frac{\pi}{3}$ & $\frac{a}{\frac{a}{0}}$ & $\begin{array}{l}= \\
\frac{y}{d} \\
3\end{array}$ & $\frac{m}{\frac{m}{2}}$ & $\begin{array}{l}\frac{n}{2} \\
\frac{\pi}{d} \\
\frac{d}{3}\end{array}$ & $\frac{7}{3}$ & $\frac{m}{2}$ & $\frac{n}{8}$ & $\frac{\pi}{3}$ & $\frac{a}{2}$ & $\begin{array}{l}= \\
\frac{y}{8} \\
3\end{array}$ & $\begin{array}{l}\frac{m}{2} \\
\frac{y}{2} \\
3\end{array}$ & $\begin{array}{l}n \\
\frac{n}{8} \\
\frac{d}{3}\end{array}$ & $\frac{\bar{y}}{\frac{y}{8}}$ & $\frac{m}{2}$ & $\begin{array}{l}n \\
\frac{y}{0} \\
3\end{array}$ & $\begin{array}{l}- \\
\frac{y}{0} \\
3\end{array}$ & $\frac{a}{d}$ & $\begin{array}{l}= \\
\frac{y}{8} \\
3\end{array}$ & $\frac{m}{\frac{m}{d}}$ & $\begin{array}{l}\frac{n}{4} \\
\frac{\pi}{2} \\
3\end{array}$ \\
\hline Meet with key stakeholders & & & & & & & & & & & & & & & & & & & & & & & & \\
\hline $\begin{array}{l}\text { Complete an organizational } \\
\text { assessment }\end{array}$ & & & & & & & & & & & & & & & & & & & & & & & & \\
\hline Discuss budget with $\mathrm{CNO}$ & & & & & & & & & & & & & & & & & & & & & & & & \\
\hline $\begin{array}{l}\text { Write a project scope and } \\
\text { share with the CNO }\end{array}$ & & & & & & & & & & & & & & & & & & & & & & & & \\
\hline $\begin{array}{l}\text { Write a project charter and } \\
\text { share with key stakeholders }\end{array}$ & & & & & & & & & & & & & & & & & & & & & & & & \\
\hline Intervention Planning & & & & & & & & & & & & & & & & & & & & & & & & \\
\hline $\begin{array}{l}\text { Create a systematic process } \\
\text { supported by evidence } \\
\text { involving the IPC team with } \\
\text { the objective to increase the } \\
\text { number of CABG patients } \\
\text { who enroll in CR }\end{array}$ & & & & & & & & & & & & & & & & & & & & & & & & \\
\hline $\begin{array}{l}\text { Plan a data deployment } \\
\text { strategy to obtain isolated } \\
\text { CABG transfer information } \\
\text { to the pilot unit }\end{array}$ & & & & & & & & & & & & & & & & & & & & & & & & \\
\hline $\begin{array}{l}\text { Plan face-to-face nursing } \\
\text { promotion intervention: } \\
\text { process, education, and } \\
\text { documentation }\end{array}$ & & & & & & & & & & & & & & & & & & & & & & & & \\
\hline $\begin{array}{l}\text { Plan the intervention for care } \\
\text { management rounding to } \\
\text { address barriers for CR } \\
\text { enrollment }\end{array}$ & & & & & & & & & & & & & & & & & & & & & & & & \\
\hline $\begin{array}{l}\text { Set guidelines for IPC } \\
\text { rounds to include CR } \\
\text { enrollment status }\end{array}$ & & & & & & & & & & & & & & & & & & & & & & & & \\
\hline
\end{tabular}




\begin{tabular}{|c|c|c|c|c|c|c|c|c|c|c|c|c|c|c|c|c|c|c|c|c|c|c|c|c|}
\hline & \multicolumn{8}{|c|}{ NUR7801 } & \multicolumn{8}{|c|}{ NUR7802 } & \multicolumn{8}{|c|}{ NUR7803 } \\
\hline 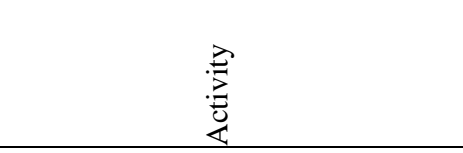 & $\frac{\bar{y}}{3}$ & $\frac{m}{y}$ & $\frac{3}{\frac{y}{8}}$ & $\frac{\pi}{3}$ & $\begin{array}{l}\frac{a}{0} \\
\frac{0}{3}\end{array}$ & $\begin{array}{l}= \\
\frac{y}{2} \\
3\end{array}$ & $\frac{m}{\frac{y}{d}}$ & $\begin{array}{l}\frac{n}{4} \\
\frac{\pi}{8} \\
3\end{array}$ & $\frac{7}{3}$ & $\frac{n}{2}$ & $\begin{array}{l}n \\
\frac{y}{8} \\
3\end{array}$ & $\frac{\pi}{3}$ & $\frac{a}{3}$ & $\begin{array}{l}= \\
\frac{\pi}{8} \\
3\end{array}$ & $\begin{array}{l}\frac{n}{2} \\
\frac{\pi}{2} \\
3\end{array}$ & $\begin{array}{l}\frac{n}{4} \\
\frac{\pi}{d} \\
3\end{array}$ & $\frac{7}{y}$ & $\frac{m}{\frac{u}{d}}$ & $\frac{n}{\frac{y}{2}}$ & $\begin{array}{l}- \\
\frac{y}{0} \\
3\end{array}$ & $\begin{array}{l}\frac{a}{y} \\
\frac{d}{3}\end{array}$ & $\begin{array}{l}= \\
\frac{y}{8} \\
3\end{array}$ & $\frac{m}{\frac{m}{d}}$ & $\frac{n}{\frac{y}{8}}$ \\
\hline $\begin{array}{l}\text { Plan an intervention for } \\
\text { ARNPs to endorse CR } \\
\text { during rounds }\end{array}$ & & & & & & & & & & & & & & & & & & & & & & & & \\
\hline $\begin{array}{l}\text { Create a checklist for the } \\
\text { process for compliance }\end{array}$ & & & & & & & & & & & & & & & & & & & & & & & & \\
\hline Measure and Analysis & & & & & & & & & & & & & & & & & & & & & & & & \\
\hline $\begin{array}{l}\text { For each measure, determine } \\
\text { the outcome measurements, } \\
\text { operational definitions, and } \\
\text { validity/reliability }\end{array}$ & & & & & & & & & & & & & & & & & & & & & & & & \\
\hline $\begin{array}{l}\text { For each measure, plan } \\
\text { ongoing assessment factors }\end{array}$ & & & & & & & & & & & & & & & & & & & & & & & & \\
\hline $\begin{array}{l}\text { Determine how each } \\
\text { intervention will be } \\
\text { monitored for fidelity and } \\
\text { completion }\end{array}$ & & & & & & & & & & & & & & & & & & & & & & & & \\
\hline $\begin{array}{l}\text { Determine quantitative } \\
\text { methods for each } \\
\text { intervention }\end{array}$ & & & & & & & & & & & & & & & & & & & & & & & & \\
\hline $\begin{array}{l}\text { Determine methods to } \\
\text { comprehend variation within } \\
\text { the data }\end{array}$ & & & & & & & & & & & & & & & & & & & & & & & & \\
\hline $\begin{array}{l}\text { Consider potential ethical } \\
\text { concerns and how to address }\end{array}$ & & & & & & & & & & & & & & & & & & & & & & & & \\
\hline Project Approval & & & & & & & & & & & & & & & & & & & & & & & & \\
\hline $\begin{array}{l}\text { Preceptor approval of the } \\
\text { project }\end{array}$ & & & & & & & & & & & & & & & & & & & & & & & & \\
\hline $\begin{array}{l}\text { Stakeholder meeting for } \\
\text { approval }\end{array}$ & & & & & & & & & & & & & & & & & & & & & & & & \\
\hline USA ERCP approval & & & & & & & & & & & & & & & & & & & & & & & & \\
\hline
\end{tabular}




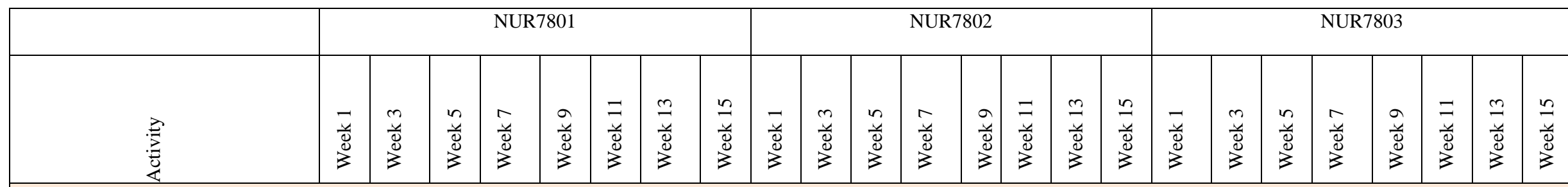

Implementation Phase

\section{Education and Training}

CR champion education via ICCPR CBL and complete post-test

GT8 nurses CR education via ICCPR CBL and complete post-test

CR education via ICCPR

CBL and complete post-test

Care management education via ICCPR CBL complete post-test, and potential barriers with solutions

Determine completion and success rates of education Project Implementation

\section{Implement face-to-face} nursing promotion of $\mathrm{CR}$ admitted with isolated CABG

Weekly surveillance of the face-to-face nursing process Implement care manager rounds with the focus to address and attempt to solve barriers expressed by the patients

Weekly surveillance of care management rounding on 


\begin{tabular}{|c|c|c|c|c|c|c|c|c|c|c|c|c|c|c|c|c|c|c|c|c|c|c|c|c|}
\hline & \multicolumn{8}{|c|}{ NUR7801 } & \multicolumn{8}{|c|}{ NUR7802 } & \multicolumn{8}{|c|}{ NUR7803 } \\
\hline 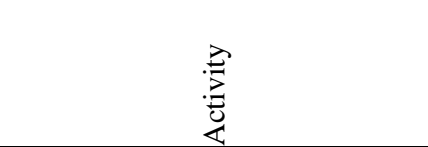 & $\begin{array}{l}\frac{7}{8} \\
\frac{y}{3}\end{array}$ & $\frac{n}{d}$ & $\begin{array}{l}n \\
\frac{u}{8} \\
3\end{array}$ & $\begin{array}{l}\frac{\pi}{0} \\
\frac{u}{3} \\
3\end{array}$ & $\begin{array}{l}a \\
\frac{u}{d} \\
3\end{array}$ & $\begin{array}{l}= \\
\frac{y}{d} \\
3\end{array}$ & $\begin{array}{l}\frac{m}{4} \\
\frac{y}{2} \\
3\end{array}$ & $\begin{array}{l}\frac{n}{4} \\
\frac{\pi}{8} \\
3\end{array}$ & $\begin{array}{l}\bar{x} \\
\frac{\pi}{0} \\
3\end{array}$ & $\frac{n}{3}$ & $\begin{array}{l}n \\
\frac{y}{8} \\
3\end{array}$ & $\frac{\pi}{3}$ & $\begin{array}{l}a \\
\frac{u}{0} \\
3 \\
3\end{array}$ & $\begin{array}{l}= \\
\frac{y}{8} \\
3\end{array}$ & $\begin{array}{l}\frac{m}{y} \\
\frac{y}{3}\end{array}$ & $\begin{array}{l}\frac{n}{y} \\
\frac{y}{d} \\
\frac{d}{3}\end{array}$ & $\begin{array}{l}\bar{y} \\
\frac{y}{0} \\
3\end{array}$ & $\frac{n}{\frac{y}{d}}$ & $\begin{array}{l}n \\
\frac{y}{8} \\
3\end{array}$ & $\begin{array}{l}\frac{1}{0} \\
\frac{0}{3} \\
3\end{array}$ & $\begin{array}{l}a \\
\frac{u}{d} \\
3\end{array}$ & $\begin{array}{l}= \\
\frac{y}{d} \\
3\end{array}$ & $\begin{array}{l}\frac{m}{y} \\
\frac{y}{d} \\
3\end{array}$ & $\begin{array}{l}\frac{n}{4} \\
\frac{y}{d} \\
3\end{array}$ \\
\hline patients to address barriers & & & & & & & & & & & & & & & & & & & & & & & & \\
\hline $\begin{array}{l}\text { Implement ARNP CR } \\
\text { promotion with rounds }\end{array}$ & & & & & & & & & & & & & & & & & & & & & & & & \\
\hline $\begin{array}{l}\text { Weekly surveillance for } \\
\text { ARNP promotion with } \\
\text { rounds }\end{array}$ & & & & & & & & & & & & & & & & & & & & & & & & \\
\hline $\begin{array}{l}\text { Implement IPC rounds to } \\
\text { discuss CR status }\end{array}$ & & & & & & & & & & & & & & & & & & & & & & & & \\
\hline $\begin{array}{l}\text { Weekly surveillance of IPC } \\
\text { rounds to ensure complianc }\end{array}$ & & & & & & & & & & & & & & & & & & & & & & & & \\
\hline $\begin{array}{l}\text { CR enrollments process } \\
\text { surveillance via weekly } \\
\text { review of the checklist }\end{array}$ & & & & & & & & & & & & & & & & & & & & & & & & \\
\hline $\begin{array}{l}\text { Discharge team provides } \\
\text { patients with enrollment } \\
\text { information and final strong } \\
\text { promotion }\end{array}$ & & & & & & & & & & & & & & & & & & & & & & & & \\
\hline $\begin{array}{l}\text { Weekly surveillance of } \\
\text { discharge team providing } \\
\text { CR promotion }\end{array}$ & & & & & & & & & & & & & & & & & & & & & & & & \\
\hline Data & & & & & & & & & & & & & & & & & & & & & & & & \\
\hline $\begin{array}{l}\text { Daily (M-F) report of } \\
\text { patients admitted to GT8 } \\
\text { with isolated CABG with } \\
\text { demographics from HIM }\end{array}$ & & & & & & & & & & & & & & & & & & & & & & & & \\
\hline $\begin{array}{l}\text { Monthly data report of } \\
\text { current CR enrollment } \\
\text { numbers of isolated CABG } \\
\text { patients from CR HIM }\end{array}$ & & & & & & & & & & & & & & & & & & & & & & & & \\
\hline $\begin{array}{l}\text { Weekly data collection of } \\
\text { patient barriers and } \\
\text { resolution via EHR }\end{array}$ & & & & & & & & & & & & & & & & & & & & & & & & \\
\hline
\end{tabular}




\begin{tabular}{|c|c|c|c|c|c|c|c|c|c|c|c|c|c|c|c|c|c|c|c|c|c|c|c|c|}
\hline & \multicolumn{8}{|c|}{ NUR7801 } & \multicolumn{8}{|c|}{ NUR7802 } & \multicolumn{8}{|c|}{ NUR7803 } \\
\hline 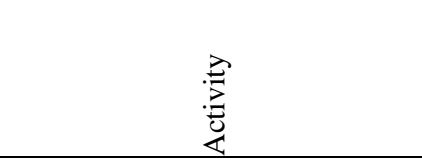 & $\frac{\bar{y}}{\frac{y}{8}}$ & $\frac{m}{3}$ & $\begin{array}{l}n \\
\frac{4}{8} \\
3\end{array}$ & $\frac{\pi}{y}$ & $\begin{array}{l}a \\
\frac{x}{0} \\
3\end{array}$ & $\begin{array}{l}= \\
\frac{y}{d} \\
\frac{d}{3}\end{array}$ & $\frac{m}{\frac{m}{2}}$ & $\frac{n}{\frac{\pi}{8}}$ & $\begin{array}{l}\bar{y} \\
\frac{7}{0} \\
3\end{array}$ & $\frac{m}{3}$ & $\frac{n}{3}$ & $\frac{\pi}{3}$ & $\begin{array}{l}a \\
\frac{y}{\Delta} \\
3\end{array}$ & $\begin{array}{l}= \\
\frac{y}{8} \\
3\end{array}$ & $\begin{array}{l}\frac{m}{2} \\
\frac{\pi}{d} \\
3\end{array}$ & $\begin{array}{l}\frac{n}{4} \\
\frac{\pi}{3} \\
3\end{array}$ & $\frac{7}{\frac{y}{8}}$ & $\frac{m}{3}$ & $\frac{n}{\frac{x}{8}}$ & $\frac{5}{8}$ & $\frac{a}{\frac{u}{d}}$ & $\begin{array}{l}= \\
\frac{y}{8} \\
3\end{array}$ & $\begin{array}{l}\frac{m}{3} \\
\frac{\pi}{3} \\
3\end{array}$ & $\begin{array}{l}\frac{n}{4} \\
\frac{\pi}{ \pm} \\
3\end{array}$ \\
\hline documentation review & & & & & & & & & & & & & & & & & & & & & & & & \\
\hline $\begin{array}{l}\text { Daily }(\mathrm{M}-\mathrm{F}) \text { data collection } \\
\text { of patients who received } \\
\text { face-to-face promotion via } \\
\text { review of checklist and } \\
\text { surveillance }\end{array}$ & & & & & & & & & & & & & & & & & & & & & & & & \\
\hline $\begin{array}{l}\text { Weekly data of patients wh } \\
\text { receive ARNP promotion } \\
\text { via the checklist and } \\
\text { surveillance }\end{array}$ & & & & & & & & & & & & & & & & & & & & & & & & \\
\hline Evaluation Phase & & & & & & & & & & & & & & & & & & & & & & & & \\
\hline Results & & & & & & & & & & & & & & & & & & & & & & & & \\
\hline $\begin{array}{l}\text { Provide details of process } \\
\text { measures and outcomes }\end{array}$ & & & & & & & & & & & & & & & & & & & & & & & & \\
\hline $\begin{array}{l}\text { Discuss contextual element } \\
\text { that interacted with } \\
\text { interventions }\end{array}$ & & & & & & & & & & & & & & & & & & & & & & & & \\
\hline $\begin{array}{l}\text { Observe relationships } \\
\text { between outcomes, } \\
\text { interventions, and context } \\
\text { elements }\end{array}$ & & & & & & & & & & & & & & & & & & & & & & & & \\
\hline $\begin{array}{l}\text { Discuss unintentional } \\
\text { consequences }\end{array}$ & & & & & & & & & & & & & & & & & & & & & & & & \\
\hline $\begin{array}{l}\text { Provide a summary of } \\
\text { missing data }\end{array}$ & & & & & & & & & & & & & & & & & & & & & & & & \\
\hline Summary & & & & & & & & & & & & & & & & & & & & & & & & \\
\hline $\begin{array}{l}\text { Summary of key findings, } \\
\text { relevance, and the aim }\end{array}$ & & & & & & & & & & & & & & & & & & & & & & & & \\
\hline $\begin{array}{l}\text { Discussion of strengths of } \\
\text { the project }\end{array}$ & & & & & & & & & & & & & & & & & & & & & & & & \\
\hline
\end{tabular}




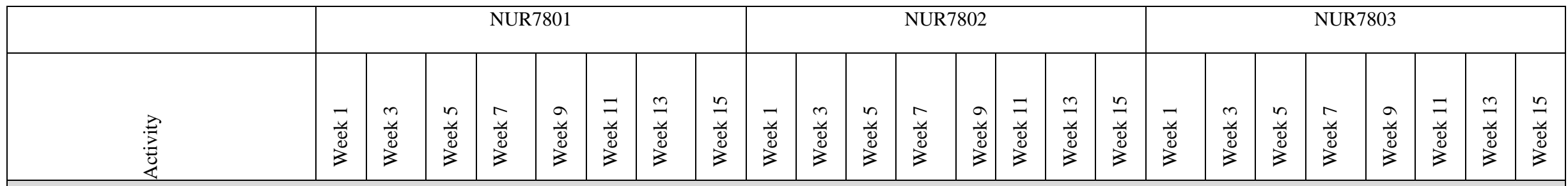

Interpretation of interventions and the number of patients enrolled in $\mathrm{CR}$

\section{Complete data collection of}

the number of patients

enrolled in CR

Face-to-face nursing

promotion

IPC rounds

\section{ARNP promotion}

Care manager barrier

resolution

Discharge nurse CR

promotion

Compliance of CR

enrollment systematic

process

Compare the project

findings with other literature

Obtain data on readmission

rates with isolated CABG

Obtain data on the cost of

CVD

Obtain the number of

isolated CABG

organizational-wide

Compare the impact of the

projects on the cost of CVD

Compare the impact of the

project on the numbers of

CABG patients in CR

Discuss any difference

between the anticipated and 


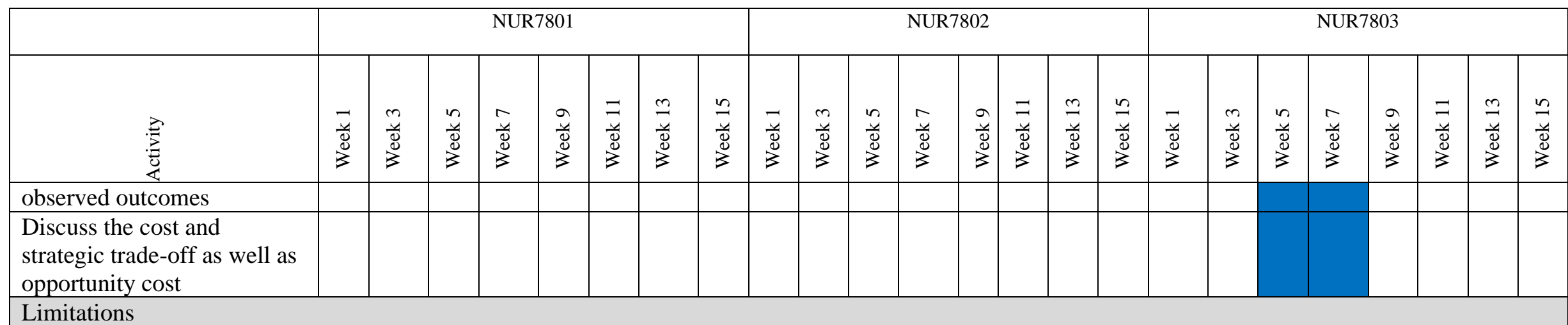

\section{Discuss the limitations of the} project and efforts made to reduce and adjust limitations

Discuss factors that might

have limited validity

Discuss efforts of the project

manager to adjust for

limitations

Conclusion

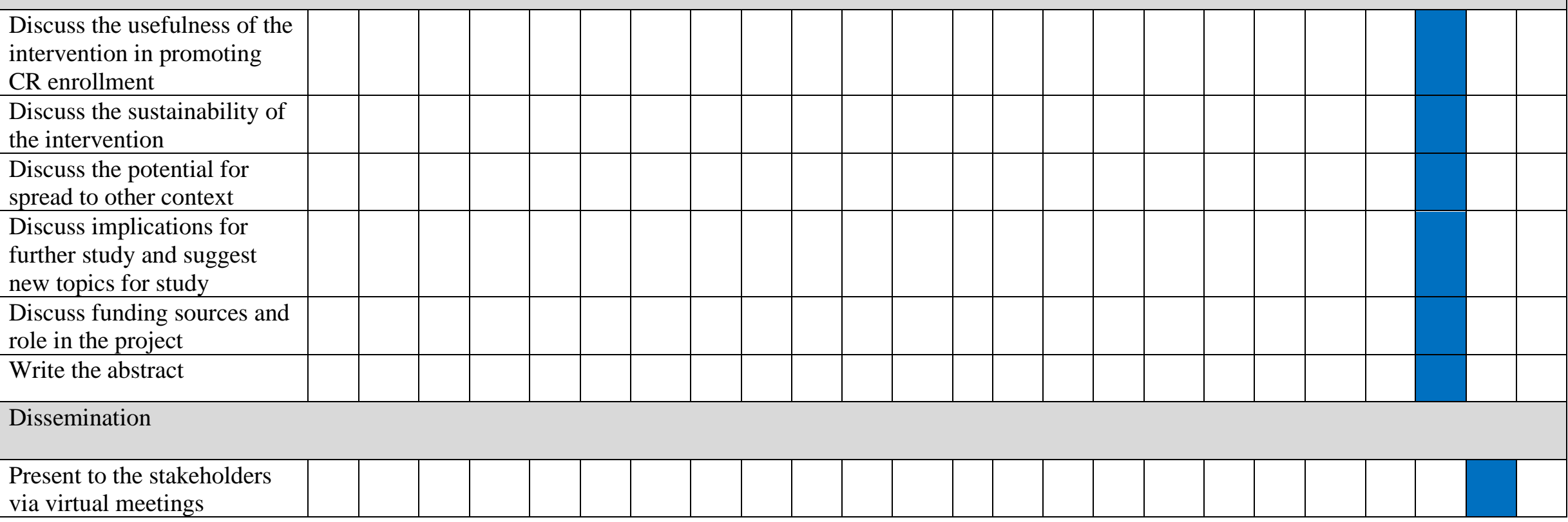




\begin{tabular}{|c|c|c|c|c|c|c|c|c|c|c|c|c|c|c|c|c|c|c|c|c|c|c|c|c|}
\hline & \multicolumn{8}{|c|}{ NUR7801 } & \multicolumn{8}{|c|}{ NUR7802 } & \multicolumn{8}{|c|}{ NUR7803 } \\
\hline 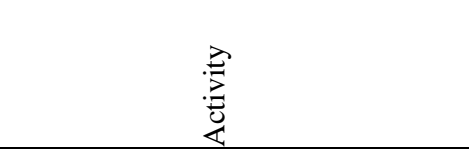 & $\frac{7}{3}$ & $\frac{n}{2}$ & $\begin{array}{l}n \\
\frac{3}{8} \\
3\end{array}$ & $\begin{array}{l}\frac{1}{3} \\
\frac{y}{3} \\
3\end{array}$ & $\begin{array}{l}\frac{a}{2} \\
\frac{u}{3} \\
3\end{array}$ & $\begin{array}{l}= \\
\frac{1}{8} \\
3\end{array}$ & $\frac{m}{\frac{y}{8}}$ & $\begin{array}{l}\frac{n}{y} \\
\frac{y}{8} \\
3\end{array}$ & $\begin{array}{l}\bar{y} \\
\frac{y}{0} \\
3\end{array}$ & $\frac{n}{2}$ & $\begin{array}{l}n \\
\frac{4}{8} \\
3\end{array}$ & $\frac{1}{3}$ & $\begin{array}{l}a \\
\frac{y}{0} \\
3\end{array}$ & $\begin{array}{l}= \\
\frac{y}{8} \\
\frac{0}{3}\end{array}$ & $\frac{m}{\frac{y}{8}}$ & $\frac{n}{\frac{n}{8}}$ & $\begin{array}{l}\bar{y} \\
\frac{y}{8} \\
3\end{array}$ & $\begin{array}{l}m \\
\frac{4}{2} \\
3\end{array}$ & $\begin{array}{l}n \\
\frac{4}{8} \\
3\end{array}$ & $\frac{\pi}{3}$ & $\begin{array}{l}a \\
\frac{y}{0} \\
3\end{array}$ & $\begin{array}{l}= \\
y \\
8 \\
3\end{array}$ & $\begin{array}{l}\frac{m}{4} \\
\frac{\pi}{3} \\
3\end{array}$ & $\begin{array}{l}\frac{n}{4} \\
\frac{4}{d} \\
\frac{d}{3}\end{array}$ \\
\hline $\begin{array}{l}\text { Present to the nursing } \\
\text { education counsel }\end{array}$ & & & & & & & & & & & & & & & & & & & & & & & & \\
\hline $\begin{array}{l}\text { Make a video presentation of } \\
\text { the project to share }\end{array}$ & & & & & & & & & & & & & & & & & & & & & & & & \\
\hline $\begin{array}{l}\text { Think about the process to } \\
\text { publish the project results }\end{array}$ & & & & & & & & & & & & & & & & & & & & & & & & \\
\hline $\begin{array}{l}\text { Prepare a poster to share at } \\
\text { scholarly events }\end{array}$ & & & & & & & & & & & & & & & & & & & & & & & & \\
\hline Celebrate! & & & & & & & & & & & & & & & & & & & & & & & & \\
\hline
\end{tabular}

Legend: ARNP: Advanced registered nurse practitioner, CABG: Coronary artery bypass graft, CNO: Chief nursing officer, CMS: Centers for

Medicare and Medicaid, CR: cardiac rehabilitation, CVD: Cardiovascular diseases, ICCPR: International Council of Cardiovascular Prevention and

Rehabilitation, IPC: Interprofessional collaboration, HIM: Health information management, STS: Society of Thoracic Surgeons 


\section{Appendix D \\ Interprofessional Team Collaboration Checklist \\ Cardiac Rehabilitation Champion (Cardiac care coordinators) \\ (document each session in the EHR patient education section) \\ Meet with the patient within 48-72 hours after transfer from ICU to GT8 \\ ○ Transfer date: \\ ○ Date and time met with patient: \\ Read the CR promotion enrollment script \\ The patient watched the informational video \\ Provided the patient the $\mathrm{CR}$ promotion packet \\ Faxed the cardiology office an order request for CR (if the patient is interested) \\ Cardiologist, fax number, date and time:}

Comments about the session:

The date of the daily visit and comments for the IPC team. Daily report to the RN, discharge nurse, care managers, and ARNP to provide promotion of CR (date and comments)

ARNP daily CR endorsement (document in the provider daily progress notes)

GT8 RN supports the patient with answering questions, promoting CR, and addressing concerns 
(document in the EHR and write a summary for the IPC team, include the date of intervention)

Care Managers (document in EHR in the case manager progress)

Meet with the patient to address barriers after the initial face-to-face promotion session by the CR champions and 72-96 hours after transfer to GT8

○ Date and time met with patient:

Barriers included:

Resolution of the barriers (if applicable):

Discharge Nurse (document in the EHR in the patient education section)

$\square$ Reviewed checklist for compliance

$\square$ Provided CR enrollment process information during discharge

$\square$ Provided a strong promotion of CR enrollment after discharge Comments of the $\mathrm{d} / \mathrm{c}$ process: 


\section{Appendix E}

\section{CR Champion Promotion Script}

Materials needed:

- Device to show a video (online)

- CR enrollment promotion packet: motivational letter, AACVPR patient education, frequently asked questions, CR locations, and the enrollment process

Hello my name is I am the cardiac rehabilitation champion at the hospital. I am here to talk to you about what happens after leaving the hospital to help you regain your cardiac health. Do you feel like talking to me for a few minutes?

Yes $\rightarrow$ take a few minutes to build a rapport with the patient No $\rightarrow$ Ok, I understand. I will come back tomorrow.

Cardiac rehabilitation is the next step after you are discharged from the hospital. Cardiac rehabilitation is a program to help people with heart disease, like yourself, to recover after a CABG. Cardiac rehabilitation will improve overall physical and mental health as well as social functioning. It helps you get back to being you!

Cardiac rehabilitation will:

- Help you feel better, reduce the risk of future heart problems, including premature death from heart disease, start healthy habits, quit smoking if you smoke, help manage stress, exercise safely being monitored by a healthcare team. This program will help you return to usual activities and live a longer, fuller life. Who would not want that!

- Cardiac rehabilitation programs help you become active in a safe environment. This program will help improve your fitness, improve your cholesterol and blood pressure, 
educate you about improvements to your diet to focus on heart health, and improve overall well-being.

To give you a better understanding of cardiac rehabilitation and what you can expect, I would like to show you a short video. Would you like to watch it?

Yes $\rightarrow$ https://www.youtube.com/watch?v=ckOHA4zSHr0

No $\rightarrow$ I understand, I will come back tomorrow to see if you are interested.

Do you have any questions or concerns right now? (answer to the best of your ability, write down questions you do not know, and follow-up with an answer)

I am also leaving you with some written information about cardiac rehabilitation that you can take home with you. Provide the CR enrollment promotion packet

During your stay, you can expect the nurses to answer your questions about cardiac rehabilitation, the nurse practitioners will speak with you about the importance and benefits, the care management team will come to address any barriers you have to attending cardiac rehabilitation, a cardiac rehabilitation champion will follow up every day with you, and the discharge nurse will provide you with information about the enrollment process to follow after you leave the hospital.

Cardiac rehabilitation is a class I A recommendation after a $C A B G$, which means research from multiple studies provide strong evidence that this treatment is very beneficial, useful, and effective. A class I A recommendation is the highest recommendation a therapy can receive. You must talk to your doctor about cardiac rehabilitation.

Here are some statistics from the CDC about people who participate in cardiac rehabilitation: 
- A $25 \%$ reduction in all-cause mortality rates

- Reduction in 10-year all-cause mortality following CABG

- Reduced symptoms, such as less chest pain, shortness of breath, and fatigue

- Improved adherence with medication

- Increased exercise performance

- $\quad$ Increased knowledge about cardiac disease and its management

- Enhanced ability to perform daily living activities

- Improved health-related quality of life

- Improved psychological symptoms, for example, a decrease in depression

- Reduced hospitalizations

- Increased ability to return to work or engage in leisure activities (CDC, 2020)

We have an excellent program located right here in the hospital if this location is close to your home; otherwise, we can help find a location closer to your home. Once the doctor order has been received, our cardiac rehabilitation team will call you to arrange for your first visit after discharge.

Thank you for allowing me to talk to you about the critical next step you need to take to get your life back. Cardiovascular disease progression is preventable with behavioral changes such as exercise, stress reduction, and eating a heart-healthy diet, which cardiac rehab will help you achieve. Do you have any questions before I leave? Have a great day and we will be back to check on you tomorrow. (script based on ICCPR recommendation: York, n.d.) 


\section{Appendix F}

Cardiac Rehabilitation Promotion Packet: Motivational letter from leadership, AACVPR patient educational flyer, frequently asked questions, locations of the cardiac rehab centers, and the enrollment process

Motivational letter:

Dear Patient, As part of your post-operative recovery, we would like to enroll you in our Cardiac Rehabilitation Program. The American Heart Association and the Centers for Disease Control and Prevention advise that all heart patients participate in cardiac rehabilitation to maximize their recovery.

Our goal through cardiac rehabilitation is to help you:

- improve your health

- prevent further problems related to your cardiovascular disease

- reduce your symptoms - and feel better!

You can expect many healthcare team members to recommend cardiac rehabilitation as your next step during your stay. If we obtain an order from your cardiologist, we can start the sign-up process in the hospital. Otherwise, the rehabilitation team will contact you at home to set up your first appointment.

Your first appointment will be an educational session to help guide you through the process. Our team will create an individualized plan to give you the best results. Remember, the program is more than just exercise. We will help you manage stress, provide health education classes, and offer information about eating a heart-healthy diet.

If you have any cardiac rehabilitation questions, please ask any healthcare team member or call us.

With best wishes for your recovery, 
Patient Cardiac Rehabilitation Education (AACVPR, n.d.)

\section{Cardiac Rehabilitation}

AACVPR

\section{An Individualized Supervised Program For You}

\section{What is Cardiac Rehabilitation?}

- An indvidualized and personalized treatment plan, including evaluation and instruction on physical actikty, nufrition, stress management, and other heath related areas

- An important part of the treatment of your specific heart problem. If you have one of the following dagnoses you msy be eligible to participate

- Heart Attack

* Angina

- Cardiac surgery, such as corconary bypass or valve surgery

- Generally covered by most heaith insurance companies but check your plan to determine copays or other requirements. Contact your local Cardiac Rehabilitation tacility to inquire what programs are avalable for patients who do not have insurance

\section{Benefits of Cardiac Rehabilitation:}

- Live langer and lessen yaur chances for anethe heart attack

- Contro heart daease axmptoma such as chess pilin or shortieses of wreath

- Stop or fexeme damage to yos hiood yesseln yeur beari

- Lessan the phyeali and emotionat etfexts at neart doease

- Improhs your starinha erd stresgth. genting you

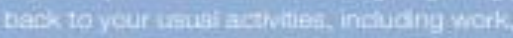
hoblies:and raguer exencite:

- improve your contidanele ena welt beng

\section{Cardiac Rehabilitation Offers:}

- Assessment of your personal risk factors for heart and biood vessel disease

- Beginning and maintaining a persconalized exercise plan that works for you

- Psychological/stress assessment and counseling
- Education and support to make healthy lifastyle changes such as:

* Maintaining a haalthy weight

* Heart healthy eating

- Avoiding tobacco and environmental smoke

- Opportunity to meet and share stories with othar patiants like you
- Monitoring and better control of

- Blocd pressure

* Upids/cholesterol

- Dabetes

- Improved communication with your doctor and other heethcare providers about your progress folowing your cardisc ewent

This intormation is prepared and presented as a service to you from the American Associstion of Carciovascular and Pulmonary Pehabilitation (AACVPF). To find the nearest Cardiac Rehablitation Center visit www.AACVPRsorn 
Cardiac Rehabilitation Frequently Asked Questions

\section{Cardiac Rehabilitation Frequently Asked Questions}

What are the benefits of cardiac rehabilitation?

- Learn to exercise safely

- Learn to manage stress

- Improve your understanding of medication and your medical conditions

- Reduce the chance of rehospitalization

- Reduce your risk of dying from a cardiac-related event by $50 \%$

- Improve your overall health and feel better!

\section{What do I need to do to get started?}

1. Speak to your doctor to receive an order to attend cardiac rehabilitation.

Who will contact me, and when?

2. A cardiac rehabilitation coordinator will contact you to set up your first appointment within two weeks of obtaining a doctor's order.

When will I start cardiac rehabilitation?

3. Ideally, you should start cardiac rehabilitation $2-4$ weeks after your CABG. Remember, you will need your doctor to write an order before you can begin.

\section{How much does cardiac rehabilitation cost?}

4. Insurance may pay for cardiac rehabilitation, and the cost will depend on your insurance plan. We will contact your insurance company for you after we receive the doctor's order.

\section{How long is cardiac rehabilitation and how often do I need to attend?}

5. The traditional rehabilitation plan is 36 sessions in total. The program lasts for 12 weeks, with three one-hour sessions each week. However, the schedule can be adjusted to fit your individual needs.

\section{What kind of exercises will I do?}

6. Exercise may include the stationary bike, recumbent bike, treadmill, elliptical machine, and free weights. Every session starts and ends with stretching. Your exercise plan is individual and based on your current health status. The cardiac rehabilitation team will closely monitor you, including your heart rate, rhythm, and blood pressure while exercising, to ensure your safety.

\section{What other services are available at cardiac rehabilitation?}

7. You will have the option to view educational videos and attend classes about health education, nutrition, and stress management. The cardiac rehabilitation team consists of nurses, exercise physiologists, dietitians, and access to the medical director. 


\section{Will I feel better?}

8. Yes, yes, yes! Research shows that people who participate in cardiac rehabilitation improve their fitness, quality of life, and report an overall feeling of improvement! 
Locations of Local Cardiac Rehabilitation Programs

\section{Cardiac Rehab Centers in Florida}

Call the center nearest you or ask your physician about participating in a Cardiac Rehab program. If you have questions or need guidance in your recovery after treatment, call Advent Health Hospital Orlando Cardiac Rehab 407-303-9360.

\begin{tabular}{|c|c|c|}
\hline $\begin{array}{l}\frac{\text { AdventHealth }}{\text { Celebration }} \\
407-303-3897 \\
400 \text { Celebration Place } \\
\text { Kissimmee, F1 } \\
\text { Fax: } 407-303-4293\end{array}$ & $\begin{array}{l}\text { AdventHealth Daytona } \\
\text { Beach } \\
386-231-3690 \\
301 \text { Memorial Medical Pkwy } \\
\text { Daytona Beach, Fl } \\
\text { Fax: } 386-231-3691\end{array}$ & $\begin{array}{l}\text { AdventHealth Deland } \\
386-943-4716 \\
701 \text { w Plymouth Ave } \\
\text { Deland, Fl } \\
\text { Fax: } 386-943-4776\end{array}$ \\
\hline $\begin{array}{l}\text { AdventHealth Fish } \\
\text { Memorial } \\
386-917-7116 \\
1055 \text { Saxon Blvd } \\
\text { Orange City, Fl } \\
\text { Fax: 386-626-6261 }\end{array}$ & $\begin{array}{l}\text { AdventHealth Heart of } \\
\text { Florida } \\
863-419-1811 \\
40101 \text { US-27 } \\
\text { Davenport, F1 } \\
\text { Fax: } 863-419-2503\end{array}$ & $\begin{array}{l}\text { AdventHealth New } \\
\text { Smyrna Beach } \\
386-424-5091 \\
401 \text { Palmetto St } \\
\text { New Smyrna Beach, } \\
\text { Fl } \\
\text { Fax: 386-424-5079 }\end{array}$ \\
\hline $\begin{array}{l}\text { AdventHealth Ocala } \\
\text { Ocala Sports Med \& Rehab } \\
352-402-5116 \\
1100 \text { SW } 1^{\text {st }} \text { Ave } \\
\text { Ocala, Fl } \\
\text { Fax: } 352-401-8844\end{array}$ & $\begin{array}{l}\text { AdventHealth Ocala } \\
\text { TimberRidge } \\
352-873-7074 \\
9521 \text { SW State Rd } 200 \\
\text { Located 1st floor } \\
\text { TimberRidge ER } \\
\text { Ocala, Fl } \\
\text { Fax: 352-873-7076 }\end{array}$ & $\begin{array}{l}\text { AdventHealth Ocala } \\
352-674-4102 \\
8550-\text { NE } 138 \text { th Lane } \\
\text { Building } 400 \\
\text { Lady Lake, Fl } \\
\text { Fax: 352-401-8844 }\end{array}$ \\
\hline $\begin{array}{l}\text { AdventHealth Orlando } \\
407-303-9360 \\
601 \text { E Rollins St } \\
\text { Orlando, Fl } \\
\text { Fax: 407-303-9601 }\end{array}$ & $\begin{array}{l}\text { AdventHealth Palm } \\
\text { Coast } \\
386-586-4480 \\
60 \text { Memorial Medical Pkwy } \\
\text { Palm Coast, Fl } \\
\text { Fax: 386-586-4644 }\end{array}$ & $\begin{array}{l}\text { AdventHealth Sebring } \\
863-386-7180 \\
4200 \text { Sun N Lake Blvd } \\
\text { Sebring, Fl } \\
\text { Fax: } 863-386-7198\end{array}$ \\
\hline $\begin{array}{l}\text { AdventHealth Waterman } \\
352-253-3396 \\
1000 \text { Waterman Way } \\
\text { Tavares, F1 } \\
\text { Fax: } 352-253-3575\end{array}$ & & \\
\hline
\end{tabular}

Scope: AdventHealth-Cardiac Rehab Updated: $12 / 17 / 2020$ 


\section{Cardiac Rehabilitation Enrollment Process}

\section{The minimum follow-up you can expect from the Cardiac Rehabilitation team is:}

- $\quad 1^{\text {st }}$ call: 24-72 hours after you leave the hospital

- $2^{\text {nd }}$ call: within 7 days after you leave the hospital

- $\quad 3^{\text {rd }}$ call: 30 days after you had your CABG surgery

\section{With each phone call, the team will:}

- follow-up with how you are doing

- answer any medical questions you have

- review your medication list with you on the initial call and with any medication changes

- strongly encourage you to start cardiac rehabilitation

\section{How to enroll in cardiac rehabilitation:}

1. Obtain an order from your cardiologist

○ You can call us, and we will send the order request to your cardiologist

2. The cardiologist's office will send the order to the cardiac rehabilitation center

3. The cardiac rehabilitation team will gather information and then contact you:

- The cost of cardiac rehabilitation specific to your health insurance

- How many one-hour cardiac rehabilitation sessions your insurance will cover

4. Our team will schedule an orientation appointment with you

- This first appointment is usually two hours 
Appendix G

Evaluation Plan

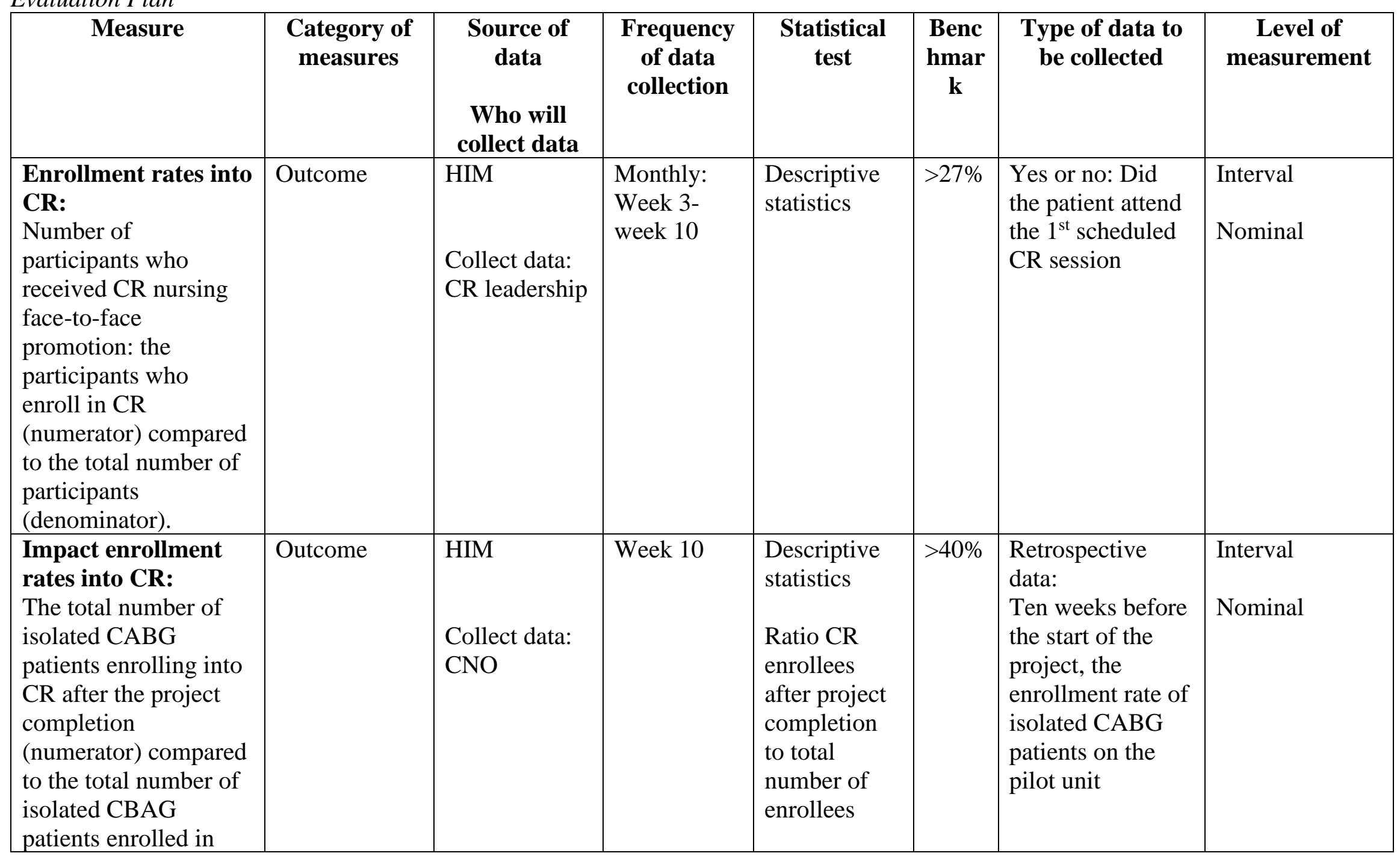




\begin{tabular}{|c|c|c|c|c|c|c|c|}
\hline $\begin{array}{l}\text { CR before } \\
\text { implementation } \\
\text { (denominator). }\end{array}$ & & & & Chi-Square & & & \\
\hline $\begin{array}{l}\text { Barriers resolved: } \\
\text { The number of } \\
\text { barriers resolved by } \\
\text { care management } \\
\text { (numerator) compared } \\
\text { to the participant's } \\
\text { total number of } \\
\text { documented barriers } \\
\text { about enrolling into } \\
\text { CR (denominator). }\end{array}$ & $\begin{array}{l}\text { Process } \\
\text { Context }\end{array}$ & $\begin{array}{l}\text { EHR } \\
\text { Collect data: } \\
\text { PM }\end{array}$ & $\begin{array}{l}\text { Weekly: } \\
\text { Week 3- } \\
\text { week } 8\end{array}$ & $\begin{array}{l}\text { Descriptive } \\
\text { statistics } \\
\text { Ratio of } \\
\text { barriers } \\
\text { resolved by } \\
\text { management } \\
\text { to total } \\
\text { number of } \\
\text { barriers. } \\
\text { Chi-square } \\
\text { test }\end{array}$ & $>15 \%$ & $\begin{array}{l}\text { Number and types } \\
\text { of barriers } \\
\text { expressed by the } \\
\text { participants } \\
\text { Number and } \\
\text { solutions for } \\
\text { barriers provided } \\
\text { by the care } \\
\text { management team }\end{array}$ & $\begin{array}{l}\text { Interval } \\
\text { Nominal }\end{array}$ \\
\hline $\begin{array}{l}\text { IPC CR education: } \\
\text { The number of the } \\
\text { IPC team members } \\
\text { who passed the CR }\end{array}$ & $\begin{array}{l}\text { Process } \\
\text { Sustainability }\end{array}$ & $\begin{array}{l}\text { Test } \\
\text { Collect data: }\end{array}$ & $\begin{array}{l}\text { Daily: } \\
\text { Weeks 1-2 }\end{array}$ & $\begin{array}{l}\text { Descriptive } \\
\text { statistics } \\
\text { Ratio }\end{array}$ & $>90 \%$ & $\begin{array}{l}\text { Pre and post-test } \\
\text { scores }\end{array}$ & Interval \\
\hline
\end{tabular}




\begin{tabular}{|c|c|c|c|c|c|c|c|}
\hline $\begin{array}{l}\text { post-test with } 100 \% \\
\text { (numerator) compared } \\
\text { to the total number of } \\
\text { IPC team members } \\
\text { who took the CR } \\
\text { education post-test } \\
\text { (denominator). }\end{array}$ & & IPC Educators & & $\begin{array}{l}\text { Chi-square } \\
\text { test }\end{array}$ & & & \\
\hline $\begin{array}{l}\text { Nursing face-to-face } \\
\text { compliance: } \\
\text { The CR champions } \\
\text { completing the initial } \\
\text { face-to-face CR } \\
\text { promotion correctly } \\
\text { (numerator) compared } \\
\text { to the total number of } \\
\text { face-to-face CR } \\
\text { promotion sessions } \\
\text { (denominator). }\end{array}$ & $\begin{array}{l}\text { Process } \\
\text { Sustainability } \\
\text { Context }\end{array}$ & $\begin{array}{l}\text { Surveillance } \\
\text { Collect data: } \\
\text { PM }\end{array}$ & $\begin{array}{l}\text { Weekly: } \\
\text { Weeks 3- } \\
\text { week } 8\end{array}$ & $\begin{array}{l}\text { Descriptive } \\
\text { statistics } \\
\text { Ratio } \\
\text { Chi-square } \\
\text { test }\end{array}$ & $>90 \%$ & $\begin{array}{l}\text { Yes or no: Did } \\
\text { the CR champion } \\
\text { provide face-to- } \\
\text { face promotion } \\
\text { following the } \\
\text { process }\end{array}$ & $\begin{array}{l}\text { Interval } \\
\text { Nominal }\end{array}$ \\
\hline $\begin{array}{l}\text { ARNP endorsement } \\
\text { compliance: } \\
\text { The number of CR } \\
\text { endorsements by the }\end{array}$ & $\begin{array}{l}\text { Process } \\
\text { Sustainability }\end{array}$ & $\begin{array}{l}\text { Surveillance } \\
\text { EHR }\end{array}$ & $\begin{array}{l}\text { Week: } \\
\text { Week 3- } \\
\text { week } 8\end{array}$ & $\begin{array}{l}\text { Descriptive } \\
\text { statistics } \\
\text { Ratio }\end{array}$ & $>90 \%$ & $\begin{array}{l}\text { Yes or no: Did } \\
\text { the cardiovascular } \\
\text { surgical ARNP } \\
\text { provide a strong }\end{array}$ & $\begin{array}{l}\text { Interval } \\
\text { Nominal }\end{array}$ \\
\hline
\end{tabular}




\begin{tabular}{|c|c|c|c|c|c|c|c|}
\hline $\begin{array}{l}\text { ARNP during } \\
\text { participant rounding } \\
\text { (numerator) compared } \\
\text { to the total number of } \\
\text { participants seen by } \\
\text { the ARNP } \\
\text { (denominator). }\end{array}$ & Context & $\begin{array}{l}\text { Collect data: } \\
\text { PM }\end{array}$ & & $\begin{array}{l}\text { Chi-square } \\
\text { test }\end{array}$ & & $\begin{array}{l}\text { endorsement for } \\
\text { CR once during } \\
\text { their patient } \\
\text { rounds. }\end{array}$ & \\
\hline $\begin{array}{l}\text { D/C RN compliance: } \\
\text { The number of } \\
\text { participants who } \\
\text { received face-to-face } \\
\text { CR promotion and } \\
\text { enrollment education } \\
\text { at the time of } \\
\text { discharge (numerator) } \\
\text { compared to the total } \\
\text { number of participants } \\
\text { discharged. }\end{array}$ & $\begin{array}{l}\text { Process } \\
\text { Sustainability } \\
\text { Context }\end{array}$ & $\begin{array}{l}\text { Surveillance } \\
\text { EHR } \\
\text { Collect data: } \\
\text { PM }\end{array}$ & $\begin{array}{l}\text { Week: } \\
\text { Week 3- } \\
\text { week } 8\end{array}$ & $\begin{array}{l}\text { Descriptive } \\
\text { statistics } \\
\text { Ratio } \\
\text { Chi-square } \\
\text { test }\end{array}$ & $>90 \%$ & $\begin{array}{l}\text { Yes or no: Did } \\
\text { the d/c RN } \\
\text { provide CR } \\
\text { promotion and } \\
\text { providing the } \\
\text { patient's } \\
\text { education about } \\
\text { the enrollment } \\
\text { process. }\end{array}$ & $\begin{array}{l}\text { Interval } \\
\text { Nominal }\end{array}$ \\
\hline $\begin{array}{l}\text { Demographics: } \\
\text { Collect data about the } \\
\text { age upon admission of } \\
\text { each participant. }\end{array}$ & Context & $\begin{array}{l}\text { EHR } \\
\text { Collect data: } \\
\text { PM }\end{array}$ & $\begin{array}{l}\text { Week: } \\
\text { Week 3- } \\
\text { week } 8\end{array}$ & $\begin{array}{l}\text { Descriptive } \\
\text { statistics }\end{array}$ & $\mathrm{n} / \mathrm{a}$ & $\begin{array}{l}\text { Range of age: } \\
\text { (0) } 18-30 \\
\text { (1) } 31-40 \\
\text { (2) } 41-50 \\
\text { (3) } 51-60 \\
\text { (4) } 61-70 \\
\text { (5) } 71-80 \\
\text { (6) } 81-90 \\
\text { (7) } 91-100\end{array}$ & Ordinal \\
\hline
\end{tabular}




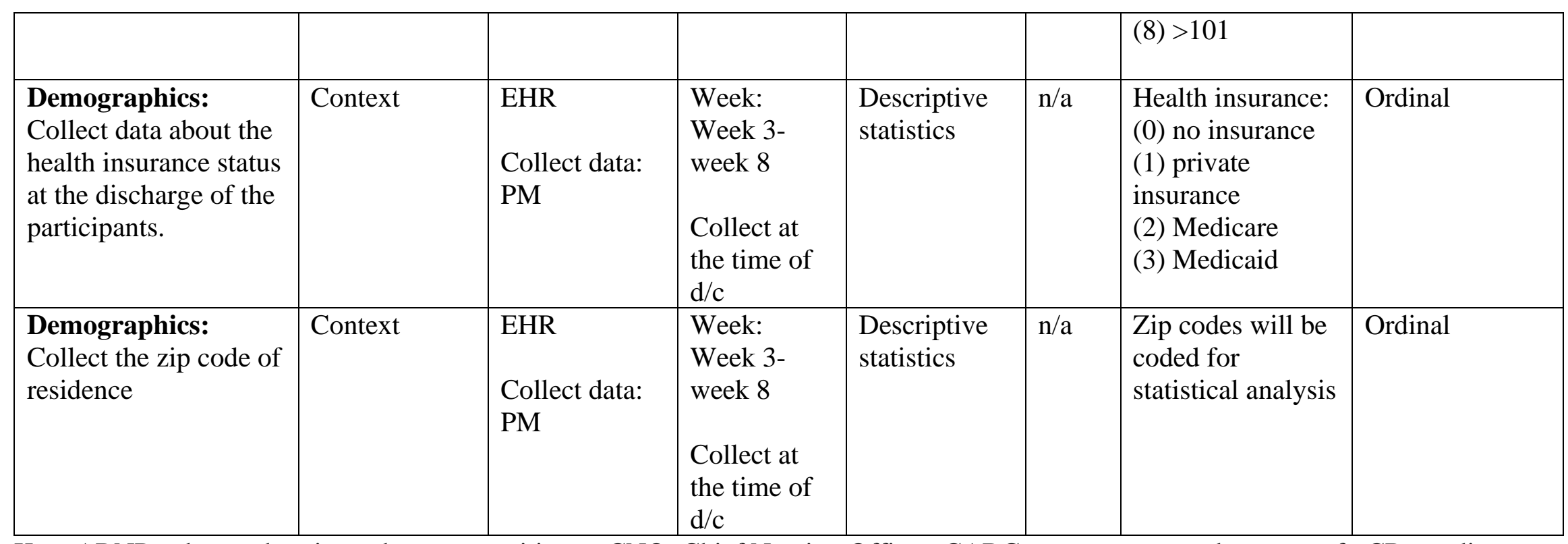

Key: ARNP: advanced registered nurse practitioner, CNO: Chief Nursing Officer, CABG: coronary artery bypass graft, CR: cardiac rehab, d/c: discharge, EHR: electronic health record, IPC: interprofessional collaboration, LOS: length of stay, PM: project manager, RN: registered nurse 
Appendix H

\begin{tabular}{l} 
Participant Data Collection Tool \\
\hline MRN
\end{tabular}

\begin{tabular}{|c|c|c|c|c|c|c|c|c|c|c|c|c|c|c|c|}
\hline MRN & Age & Gender & $\begin{array}{c}\text { Health } \\
\text { insurance }\end{array}$ & $\begin{array}{l}\text { Zip- } \\
\text { code }\end{array}$ & $\begin{array}{c}\text { Transfer } \\
\text { date }\end{array}$ & $\begin{array}{l}\mathrm{D} / \mathrm{C} \\
\text { date }\end{array}$ & $\begin{array}{c}\text { CR } \\
\text { promotion }\end{array}$ & $\begin{array}{c}\text { ARNP } \\
\text { promotion }\end{array}$ & $\begin{array}{c}\text { D/C } \\
\text { enrollment } \\
\text { process }\end{array}$ & $\begin{array}{c}\text { IPC } \\
\text { rounds }\end{array}$ & $\begin{array}{c}\text { Expressed } \\
\text { barriers }\end{array}$ & $\begin{array}{l}\text { Barrier } \\
\text { resolution }\end{array}$ & $\begin{array}{c}\text { Participant } \\
\text { questions } \\
\text { concerns }\end{array}$ & $\begin{array}{c}\text { CR } \\
\text { enrollment }\end{array}$ & $\begin{array}{c}\text { RN } \\
\text { support }\end{array}$ \\
\hline & & & & & & & & & & & & & & & \\
\hline & & & & & & & & & & & & & & & \\
\hline & & & & & & & & & & & & & & & \\
\hline & & & & & & & & & & & & & & & \\
\hline & & & & & & & & & & & & & & & \\
\hline & & & & & & & & & & & & & & & \\
\hline & & & & & & & & & & & & & & & \\
\hline & & & & & & & & & & & & & & & \\
\hline & & & & & & & & & & & & & & & \\
\hline
\end{tabular}

Legend:

Gender: Data collection: (0) female, (1) male, (2) Binary, (3) no gender

Health insurance: (0) no insurance, (1) private insurance, (2) Medicare, (3) Medicaid

Range of age: (0) 18 - 30, (1) 31 - 40, (2) 41 - 50, (3) 51 - 60, (4) 61-70, (5) 71-80, (6) 81-90, (7) 91-100, (8) >101

Zip code: to be determined based on each participants residence

Barriers: to be determined based on each participants response 